\title{
LA REFORMA DE LA PREDICACIÓN EN LA ORDEN IGNACIANA. EL NUEVO PREDICADOR INSTRUIDO (1740) DE ANTONIO CODORNIU*
}

\author{
Francisco Luis RICO CALLADO
}

Universidad de Alicante

\begin{abstract}
Resumen
La orden jesuita fue uno de los focos de la reforma de la predicación emprendida por los autores antibarrocos en la España del siglo XVIII. La obra de Antonio de Codorniu, que se analiza en este artículo es uno de los ejemplos más claros. Esta obra comparte algunos de los rasgos esenciales de las obras de preceptiva retórica reformista del Setecientos y, al mismo tiempo, de las actitudes de los jesuitas que siguieron fieles a la escolástica y ajenos a algunas de las aportaciones más destacadas de los rigoristas españoles.
\end{abstract}

\begin{abstract}
The Company of Jesus was one of the origens of the preaching reform started by the antibaroque authors in the Spain of the XVIII Century. Antonio de Codorniu's play, which is commented in this article, is one of the clearest examples. This book shares some of the essential characteristics of works of preceptive reformist eighth century rhetoric and, at the same time, the attitudes of those jesuits loyal to the Scholastic and out of step with the contributions of the more inflexible Spanish.
\end{abstract}

La reforma de la predicación en la España del siglo XVIII se caracterizó por el intento de recuperar el rigor dogmático y moral en los púlpitos de la época. Este empeño tiene, sin duda, raíces muy anteriores, ya que los reformistas no sólo recuperaron las ideas de los tratadistas del Quinientos que pretendièron una renovación de la oratoria sagrada sino que su labor supuso, por otro lado, una continuación de la lucha

(*) Este artículo es fruto de una tesis doctoral que su autor está realizando sobre la predicación en la España del siglo XVIII. Este trabajo ha sido posible gracias a una beca pre-doctoral concedida por la Generalitat Valenciana. Los primeros resultados han sido expuestos en una tesis de licenciatura presentada en octubre de 1999 en la Facultad de Filosofía y Letras de la Universidad de Alicante con el título: La reforma de la predicación en la España del siglo XVIII. Su director es el Dr. Enrique Giménez López. 
emprendida por una parte importante de los tratadistas de retórica sacra del siglo XVII '. Podemos concluir, pues, que los caracteres esenciales de la reforma de la predicación en el Setecientos carecieron, en gran medida, de originalidad ${ }^{2}$.

En cuanto a los principios retóricos, se puede establecer un claro parangón entre las ideas defendidas por los preceptistas dieciochescos, entre los que se cuenta Codorniu, y las afirmaciones de los primeros teóricos y oradores de la retórica cristiana, entre los que destaca San Agustín. Joël Saugnieux subrayó el parentesco que existía entre ambos períodos ${ }^{3}$. La Biblia se convirtió en ambos momentos en el centro de la predicación lo que supuso la aplicación de unos principios estrictos entre los que debemos destacar la oposición entre el Verbum (o palabra divina, encarnada en la Biblia) y el verbum (humano) ${ }^{4}$. El primero, que es el que nos interesa, se caracteriza por la sencillez, muy obvia en las homilías de los siglos IV y V y, en segundo lugar, por la autenticidad y una enorme fuerza. Ello condujo, en definitiva, a un intento de abandonar o poner en sus justos límites la oratoria que había sido afectada por el estilo vacío y los excesos retóricos que caracterizaron a la Segunda Sofística ${ }^{5}$. Hemos de considerar, sin embargo, que esta toma de posición respecto a la retórica clásica no supuso, en absoluto, un abandono del ornato retórico y, en definitiva, de las enseñanzas de los grandes oradores clásicos ${ }^{\circ}$. Así pues, la primera articulación sistemática de la oratoria cristiana, aunque insuficiente, ya que no permitió la aparición de una nueva retórica totalmente alejada de la pagana, se encuentra en De Doctrina Cristiana de San Agustín?

1. Que podemos caracterizar como conservadores y que se opusieron a la predicación barroca. Hay buenos ejemplos de esta oposición al nuevo estilo de predicar en el siglo XVII. Fr. Andrés de Valdecebro, autor de El orador católico atento y advertido, Madrid, 1655, declaró que aunque «... el discurso debía estar adornado o aliñado, era inaceptable «(...) la oscuridad de las palabras, del lenguaje afectado de la ostentación de hinchazones vanas e inútiles, de sentencias, fábulas y versos de gentiles y del decir gracias vanas y groseras»» (HERRERO SALGADO, F.: La oratoria sagrada española de los SS.XVI-XVII. Madrid, FUE, 1998, p. 237).

2. Esta ha sido una de las tesis fundamentales que hemos defendido en nuestra memoria de licenciatura. En ella se pueden encontrar amplios detalles sobre la reforma de la predicación en la España del Setecientos, tanto en los aspectos retóricos como en los ideológicos.

3. El modelo retórico está, en opinión de Codorniu, en San Pablo. Al menos esta es su posición en un escrito posterior: Práctica de la palabra de Dios en varios sermones panegíricos dirigida a los ministros del evangelio y dedicada al apóstol San Pablo, Barcelona, 1756; pueden verse comentarios sobre esta obra en SAUGNIEUX, J.: Les jansénistes et le renouveau de la prédicaton dans l'Espagne de la seconde moitié du xiècle XVIII. Presses universitaires. Lyon, 1976, p. 95. Sin embargo, en la obra que comentamos en este artículo el modelo que se destaca más a menudo es, claramente, el portugués A. Vieyra.

4. HERNÁNDEZ GUERRERO, José Antonio y GARCÍA TEJADA, María del Carmen: Historia breve de la retórica. Editorial Síntesis. Madrid, 1996, p. 73.

5. Ibid., p. 73.

6. Así lo reconoció San Ambrosio (ibídem). En otros autores, como San Jerónimo, se «... yuxtaponen la reprobación y la aceptación de los procedimientos retóricos» (ibídem).

7. Tras las aportaciones de San Pablo o la experiencia retórica de la predicación de Cristo, la obra de San Agustín supuso un esfuerzo por establecer una cultura cristiana y, por supuesto, una nueva oratoria alejada de la oratoria clásica ciceroniana. San Agustín no desechó, obviamente, la retórica pagana sino que 
Joël Saugnieux estableció un estrecho parentesco entre la actitud de los Santos Padres, los retóricos del Gran Siglo francés y, por extensión, de los reformistas españoles del Setecientos ${ }^{8}$. Uno de los modelos que retomaron fue San Gregorio Nacianceno, en cuya obra «on s'aperçoit (...) comme chez les meilleurs orateurs français du Gran siècle, le souci de la forme ne conduit pas au formalisme et que l'homme est moins "rhé-

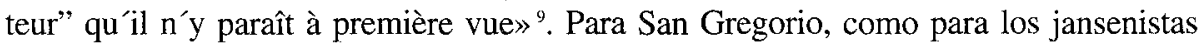
franceses, importa mucho más la santidad del predicador que el dominio de la retórica. Se trata, pues, de una actitud totalmente opuesta al lenguaje tortuoso y enigmático que imperaba tanto en los sermones franceses del Seiscientos como en la predicación barroca española coetánea, que siguió presente en nuestros púlpitos durante el siglo XVIII. Buena muestra de la misma actitud rigorista son las declaraciones de Bérulle ${ }^{10}$. Por ello, los jansenistas intentaron imponer la sencillez del discurso que, en su opinión, estaba ligada a la transmisión del Verbo divino. Volveremos sobre esta cuestión más adelante.

Tanto para los autores jansenistas como para muchos otros, entre los que se encuentran Fenelon, Bossuet o La Bruyère, el orador sagrado debía huir de la belleza formal. Según La Bruyère: «la prédication rebute les beaux esprits car on n'y brille

pretendió adaptarla a las nuevas circunstancias. A pesar de ello, su esfuerzo se puede calificar como fallido. Tras él se abrió un largo período de despreocupación respecto a la retórica, quizá porque existían asuntos más urgentes en los que sí que se produjeron aportaciones de importancia: las controversias sobre el celibato de los sacerdotes, la divinidad de Cristo, etc. (MURPHY, James J.: La retórica en la Edad Media: historia de la teoría retórica desde San Agustín hasta el Renacimiento. Ed. FCE. México, 1986, p.291). Por otro lado, los primeros siglos de vida de la nueva fe bajo una persecución continuada no permitirieron la «...elaboración de ninguna clase de teorías (retóricas)» (ibid., p. 291).

Los jesuitas tuvieron, pues, una justificación para emplear los clásicos ya que habían sido utilizados por los Santos Padres. Existen, sin embargo, otras razones «... d’ordre pédagogique et psychologique: l'élevation des pensées qu'on trouve dans les auteurs chrètiens dépassait la portée de beaucoup d'enfants; ils n'y trouvaient pas cette «pâture» dont a besoin l'imagination du jeune âge. Quel ennui suivrait de toutes ces pieuses méditations du jeune âge». (DAINVILLE, F.: L'éducation des jésuites: XVI (e)-XVIII(e) siècles. Ed. Minuit. París, 1991, p. 180).

8. Debemos tener mucho cuidado a la hora de precisar la influencia que tuvieron las obras francesas en nuestra oratoria sagrada dieciochesca. En primer lugar, hemos considerar que los grandes oradores franceses fueron, como reconoció Saugnieux, más citados que leídos. Por otro lado, debemos apuntar una importante presencia de autores y preceptistas de otras nacionalidades, hasta el punto de que podemos hablar de una influencia italiana o portuguesa de la que son buena prueba autores tan esenciales en nuestras preceptivas dieciochescas como Muratori, Segneri o, sobre todo, Vieira. Finalmente, no podemos olvidar que, como hemos demostrado en nuestra tesis de licenciatura y se puede comprobar siguiendo algunos escritos de Félix Herrero Salgado, muchos de los principios defendidos por los preceptistas dieciochescos se encuentran en los manuales de oratoria sagrada del Seiscientos. En consecuencia, sin negar el calado de las obras francesas, que acabó convirtiéndose en una moda, debemos poner en duda que llegase a ser tan determinante en nuestra reforma como se ha sostenido muchas veces.

9. SAUGNIEUX, J.: Les jansénistes et le renouveau de la prédication dans l'Espagne du XVIII(e) siècle, p. 75 .

10. Bérulle afirmó que no se debía buscar la satisfacción del público sino simplemente enseñar y mover: «Quant au reste des ornements du langange, je n'y ai pas voulu seulement penser, ayant assez d'autres choses à faire» (citado en ibid., p. 97). 
pas facilement (...) il faut marcher par des chemins battus, dire ce qui a été dit et ce que l'on prévoit que vous allez dire. Les matières sont grandes mais usées et triviales (...). (L'orateur) doit tirer son discours d'une source commune, où tout le monde puise, et s'il s'écarte de ces lieux communs, il n'est plus populaire, il est abstrait et déclamateur, il ne prêche plus 1"Evangile» ". Por lo tanto el empleo de la retórica está limitado y sirve para ilustrar y hacer comprensible la palabra de Dios ${ }^{12}$.

En claro contraste con los rigoristas, influidos por los jansenistas franceses, la historiografía relacionada con la oratoria sacra ha distinguido otras corrientes. En primer lugar, tendríamos a los barroquistas, continuadores de la letra, que no el espíritu, del Barroco; podemos contar entre ellos a los gerundistas descritos por el Padre José Francisco de Isla ${ }^{13}$. En segundo lugar, hay otro grupo de reformistas que hacen hincapié en el papel de la retórica, de la sabiduría y de la razón, entre los que algunos investigadores cuentan a Isla y, en general, a los jesuitas ${ }^{14}$. Buena muestra de este segundo grupo es, según Ramón Baldaquí, Leonardo Soler de Cornellá que: «Justifica el uso del arte por el predicador, y señala que se predicará con humildad y caridad; pero estas oservaciones son puntos aislados en un mar de enseñanzas retóricas, y Soler no se ocupa de la figura moral del predicador, silencia cuál debe ser su talante y comportamiento en la plegaria y meditación, ni su ejemplo para edificación de los fieles» ${ }^{\text {is }}$.

11. Citado en BLANCO, Mercedes: «La Critique de la prédication conceptiste au XVIII(e) sièclè en Mélanges de la Casa de Velázquez, tomo XXIV(1988), p. 157.

12. Autores cercanos al rigorismo, a los que no nos atrevemos a calificar como jansenistas, limitaron en cierta medida, «... le goût du savoir, l'amour des belles choses, et a fortiori ce goût frivole de la variété et de la nouveauté, que flattent les prédicateurs conceptistes» (ibídem, p. 158). Sin embargo el modelo ideal de orador propuesto por Mayans está muy cerca del conceptista más puro: «L orateur doit être savant, doit connaître à fond l'Ecriture et la théologie, mais aussi n'ignorer rien d'essentiel en ce qui concerne la philosophie, les lettres profanes ou l'histoire, surtout ecclésiastique. La seule différence entre cet orateur presque omnisciente et l'orateur conceptiste réside en ce que le premier dissimule plus habilement son savoir pour mieux l'intégrer dans la texture intime de son discours» (ibid., p. 158). Cosa que se ve claramente en algunos fragmentos de la obra de Mayans El orador christiano.

Es más, según los jansenistas el predicador no debía atender al modo de exposición empleado por los clásicos: «Ainsi Fénelon dans les Dialogues sur l'eloquence propose qu'on renonce à ce modèle argumentatif et qu'on fasse du sermon une paraphrase linéaire du récit évangélique, une explication littérale de l'Ecriture» (BLANCO, Mercedes: «La Critique de la prédication...», p. 159).

13. Sus rasgos están muy bien descritos en el artículo de BLANCO, Mercedes: «La Critique de la prédication...», pp. 167 y ss. Félix Herrero Salgado estableció hace años una clasificación en tres grandes grupos de las corrientes oratorias del Seiscientos. A la tercera pertenecen los gerundistas (puede verse esta clasificación en CERDÁN, Francis: Introducción a SORIA ORTEGA, A.: El maestro Fr. Manuel de Guerra y la oratoria sagrada de su tiempo. Ed. Universidad de Granada. Granada, 1991, pp. XIII-XIV).

14. BALDAQUÍ Y ESCANDELL, Ramón: «La reforma de la predicación en el XVIII valenciano: Leonardo Soler de Cornellá». Anales Valentinos, 1985, p. 121. Es decir, un grupo apegado al escolasticismo y que adopta una actitud muy peculiar y encontrada con otros reformistas, que nosotros hemos calificado como rigoristas y que autores como Saugnieux llaman jansenistas, que se caracterizarían por sufrir «... la contaminación del espíritu secularizador y del racionalismo de la época» (ibid., p. 123).

15. BALDAQUÍ Y ESCANDELL, Ramón: «La reforma de la predicación en el XVIII valenciano: Leonardo Soler de Cornellá», p. 124. 
Estas actitudes encontradas se explican, por una clara diferencia en la concepción del hombre. Como es sabido, los jansenistas insistieron en el papel protagonista de la Gracia tanto en la salvación como en la vida de la sociedad cristiana. Por el contrario, para autores como Soler de Cornellá, la «...acción humana puede facilitar la actuación de la Gracia divina, y colaborar eficazmente en la Fe, hasta el punto de que por medios puramente humanos puede inducirse ésta (...)» ${ }^{15}$. En palabras del obispo Felipe Bertrán: «(El)... espíritu de Dios conmueve más los ánimos que toda la eloquencia humana» ${ }^{17}$. Sin embargo, pese a la importancia de la Gracia, esto es, la inspiración divina en la labor del predicador, los medios humanos siguen ocupando un papel de gran importancia en autores que han sido considerados jansenistas; un buen ejemplo de ello es Gregorio Mayans. ¿Podemos hablar rigurosamente de jansenismo en sus concepciones? ${ }^{18}$

Posiblemente, uno de los caracteres que pueden permitir delimitar mejor esta cuestión son las reflexiones que hacen estos autores, y especialmente Gregorio Ma-

16. Ibid., p. 130.

17. Citado en ibid., p. 131.

18. Aunque este no es el asunto de este artículo, debemos matizar nuestras afirmaciones. La oración y la meditación, que tanta importancia tienen para lograr el apoyo de Dios (como reconoce BALDAQUí Y ESCANDELL, Ramón: «La reforma de la predicación en el XVIII valenciano: Leonardo Soler de Cornellá», p. 130), jugaron un papel protagonista en la religiosidad española del siglo XVI y, concretamente, en la predicación. Esta característica se entrevé claramente en las obras de Juan de Ávila o de Fray Luis de Granada. En efecto, para ambos, de la oración se emanaba una acción posterior. Es más, gracias a la oración el sermón se hacía más apasionado y emotivo, el orador se descubría a sí mismo y, lo que no es menos importante, obtenía la ayuda de Dios. En una de sus cartas, dirigida a un predicador, Juan de Ávila pondera la importancia de la meditación realista, indicando al destinatario una serie de acciones: «Piense con atención en el paso de su muerte lo más entrañablemente que pudiere, como si en ella estuviese, notando particularmente cómo estará en la cama, la candela en la mano, y todo lo demás que el Señor le diere; y tras ésto, cómo, salida el ánima, quedará acá el cuerpo y será llevado a enterrar. $Y$ haga cuenta que oye los cantos y lloros y todo lo demás que se suele hacer, y cómo, echado su cuerpo debajo la tierra, será hollado, y quizá de los animales, y podrá ser que anden los huesos rodando. Y pues esto ha de venir, haga cuenta que ha venido, y dése por muerto a este mundo, volviendo de verdad las espaldas y echando de su corazón toda criatura, y todo amor de honra, y todo temor de deshonra; y haga cuenta ya está en el otro mundo, y viva acá como en una inmutabilidad entre las mudanzas, mirando cómo ya es todo pasado, y él y los que ve están ya olvidados, y todo se ha ya pasado, ansí como agua que corrió con zurrido» (ÁVILA, Juan de: Obras completas. Tomo V: Epistolario. Ed. BAC. Madrid, 1970. Carta V, p. 49). Hay otras indicaciones de interés en esta carta.

Sobre esta misma cuestión se pueden consultar algunos escritos biográficos de Juan de Ávila, en los que se subraya la importancia de la oración y de la meditación en la labor del predicador:

«No predicaba sermón sin que por muchas horas la oración le dirigiese. Allí se acrisolaban los conceptos y se les infundía vida; allí se les daba corte a las razones que herían en los corazones más duros; tomaban viveza sus palabras, más penetrantes que espada de dos filos; aquí se renovaba el espíritu, y aumentaban vigor aquellos ímpetus que se ejecutaban en el púlpito; en la oración suplicaba Nuestro Senor íntimamente diese virtud y eficacia a sus palabras, pedía la conversión de las almas, en ella negociaba el trueco de los corazones, la mudanza de las vidas» (MUNOZ, Luis: «Vida y virtudes del venerable varón el P. Maestro Juan de Ávila, predicador apostólico». Madrid, 1635. En GRANADA, Fr. Luis de y MUNOZ, Luis: Vidas del Padre Maestro Juan de Ávila. Ed. Juan Flors. Barcelona, 1964, p. 187). 
yans ${ }^{19}$, sobre el establecimiento de unos límites claros entre el buen estilo y el uso inadecuado de la retórica, propio de la tendencia barroquista. Sin embargo, podemos decir que ambas posturas se confunden muchas veces. En ciertos aspectos no podemos establecer unas distancias claras entre las afirmaciones de los reformistas y el estilo barroquista ${ }^{20}$; de ello son buena prueba tanto los consejos retóricos dados por los autores dieciochescos como los modelos propuestos ${ }^{21}$. Sin embargo, debemos reconocer que, desde el punto de vista doctrinal, la predicación reformista del Setecientos se caracterizó por una mayor rigurosidad que los sermonarios decadentes.

La obra del Padre Codorniu tiene un gran interés para conocer los caracteres de la reforma de la predicación emprendida en la España del siglo XVII ${ }^{22}$. Debemos hacer notar que este escrito se incardina en una corriente «jesuita» que desde el Seis-

Fr. Luis de Granada destacó también la importancia de la oración en la actividad pastoral de Juan de Ávila; en uno de los capítulos de su biografía de Juan de Ávila, titulado «De los medios con los cuales se consiguió el fruto y aprovechamiento de las ánimas, de que hasta aquí se ha tratado», dice que:

«(...) entre las ayudas de que él (Juan de Ávila) se aprovecho para este efeto, la primera y más principal era la oración, suplicando intimamente a Nuestro Señor diese virtud y eficacia a su palabra; acordándose que, como la red de San Pedro, trabajando toda la noche con fuerzas humanas, ningún pece (sic) había prendido, mas ayudada con las divinas, hinchió (sic) ambas las navecicas de ellos, entendió este varón de Dios que esto mismo acaece a los predicadores en esta pesquería espiritual de las ánimas; y por esto acudía él a Nuestro Señor en la oración, diciéndole que en su nombre tendería la red. Esta era la primera y más principal ayuda de que este pescador se valía para este oficio; afirmando que los hijos espirituales que con la predicación se ganaban, más eran hijos de lágrimas que no de palabras» (GRANADA, Fr. Luis: «Vida del Padre Maestro Juan de Ávila y las partes que ha de tener un predicador del Evangelio», Madrid, 1588. En GRANADA, Fr. Luis de y MUNOZ, Luis: Vidas del Padre Maestro Juan de Ávila, pp. 178-9).

La oración y la meditación siguieron destacándose como instrumentos importantes de la labor del predicador sin llegar, al menos no tenemos pruebas suficientes, a destacarse tanto como en autores como Juan de Ávila o Mayans.

19. Este autor ha sido considerado uno de los grandes pioneros de la reforma de la predicación en el Setecientos. Es autor de un conocido tratado de oratoria sagrada titulado: «El orador christiano» en Obras completas. Tomo II. Ed. Ayuntamiento de Oliva, 1984.

20. Buena prueba de ello son los trabajos de Mercedes Blanco que llega a afirmar que en la obra de Mayans existen elementos que podían propiciar el conceptismo: «...Mayans est en fait infiniment moins radical et donc moins cohérent que celui des jansénistes du XVII(e) siècle. Après avoir condamné l'éloquence conceptiste au nom de la simplicité du message évangélique, Mayans sera réduit à glisser dans la partie constructive de son ouvrage de ce registre religieux à un registre purement humain, raisonnable et esthétique. L'idéal qu'il oppose au conceptisme condamné relève d'une rhétorique plus raffinée plutôt que du dénuement de l'apôtre.» (BLANCO, Mercedes: «La critique de la prédication...», p. 156).

Esa aplicación, casi al pie de la letra, de los principios retóricos de Cicerón y de otros oradores clásicos hizo que «Mayans ne s'aperçoit pas que la logique même de l'oratio appliquée aux matières qui font l’objet du sermon doit dériver presque nécessairement vers l`ingéniosité conceptiste» (ibid., p. 158).

21. En nuestra memoria de licenciatura hemos desarrollado por extenso estas influencias centrándonos en aspectos que no habían sido estudiados hasta el momento.

22. Saugnieux destacó, hace años, que esta obra «a... le double interêt d'apparaître dans la première partie du siècle et d'être l'oeuvre d'un jésuite. Il témoigne que l'idéal de prédication évangélique ne s'affirme pas seulement dans les dernières années du siècle et qu'il ne trouve pas seulement des défenseurs 
cientos pretendió la recuperación de una oratoria sagrada más rigurosa en la que podemos encuadrar también las obras del Padre José Francisco de Isla, tanto su Crisis de los predicadores y de los sermones ${ }^{23}$, como su conocidísimo Fr. Gerundio.

Podemos afirmar que una parte importante de los principios rectores de la reforma emprendida en esta centuria se encuentran en la obra de Codorniu auque, obviamente, este escrito tiene unos rasgos específicos que la distinguen.

\section{LA DECADENCIA DE LA ORATORIA SAGRADA Y EL PAPEL DE LA ORDEN DE SAN IGNACIO EN LA REFORMA DE LA PREDICACIÓN}

Una de las razones fundamentales que explican la decadencia de la predicación en el siglo XVIII fue la influencia que ejerció el Barroquismo en la oratoria sagrada ${ }^{24}$. Esta tendencia, que buscaba la exhibición del ingenio y de novedades en los sermones se encontraba, en cierta medida, implícita en el propio modelo educativo jesuita. En efecto, a pesar de que en la Ratio Studiorum, la imitación de los modelos propuestos fue clave en la enseñanza de la retórica, existían en su seno ciertas contradicciones que permitieron la proliferación del conceptismo en la orden ignaciana ${ }^{25}$. Sin duda, el espíritu de emulación de los clásicos cedió ante una cierta libertad que estaba implícita en la misma Ratio, pese a las protestas de fidelidad a los modelos que limitaban, sobre el papel, cualquier tipo de veleidad por parte de los alumnos:

«...a la estética aristotélica de la imitación, que es la que respira la entera Ratio Studiorum, le sucede la estética de la invención. Pero aun en este terreno la Ratio oficial abría un portillo a la libre inventiva mediante el ejercicio de los emblemata o empresas: la Ratio las permitía, en determinadas ocasiones, a los estudiantes de Letras en general, y las recomendaba a los del curso de Retórica modice tamen. Bastó hacer caso omiso del modice para explicarnos toda la floración de odas jeroglíficas que caracterizó la literatura peyorativamente jesuítica de la décima-séptima centuria» ${ }^{26}$.

De este modo, A. Martí concluye que obras como la Agudeza y arte de ingenio de Gracián «...están plenamente dentro de la Ratio, e incluso dentro del espíritu de la imitación de Aristóteles, quien ya en su tiempo pareció echar los cimientos de lo que iba a ser el Barroco. Gracián no hizo más que empujar y acelerar un proceso que, en

chez les adversaires de la Compagnie» (SAUGNIEUX, J.: Les jansénistes espagnols et le renouveau de la prédication, p. 95).

23. ISLA, José Francisco de: Crisis de los predicadores y de los sermones. Ed. Universidad Pontificia Comillas, Madrid, 1994.

24. La relación de la oratoria sagrada dieciochesca con el Barroco no ha merecido, hasta el momento, estudios sistemáticos. Una introducción y algunas aportaciones novedosas en: RICO CALLADO, Francisco Luis: La reforma de la predicación en la España del siglo XVIII. Alicante, 1999, pp. 9-84

25. Empleamos el término conceptismo para referirnos al uso de conceptos tan típico en la literatura barroca y, por extensión, en la predicación de la época. Sin embargo, debemos apuntar que la diferenciación en dos movimientos opuestos (conceptismo-culteranismo) es errónea, como se han encargado de demostrar numerosos estudios sobre la literatura barroca.

26. BATLLORI, M.: Gracián y el Barroco, Roma 1958, citado por MARTí, A.: La preceptiva retórica en el Siglo de Oro. Ed. Gredos, Madrid, 1972, p. 290. 
realidad, hacía ya tiempo que estaba desencadenado... no se apartó de la legislación de los estudios de la Orden. Es de notar que la Compañía... persiguió el Barroco en el campo de la predicación y producción literaria y, sin embargo, dejó florecer y aceptó las producciones más exacerbadas del mismo sistema estético en otros campos del arte, como podemos ver por doquier en las iglesias jesuitas barrocas ${ }^{27}$.

Sin embargo, debemos hacer algunas precisiones. Es cierto que si bien algunos autores jesuitas promovieron la oratoria sagrada al estilo barroco, la reforma de la predicación tuvo en la orden jesuita uno de sus primeros focos. Así pues, podemos entrever la coexistencia de dos corrientes retóricas en la orden ignaciana, una conservadora y otra promovida por algunos autores, entre los que destaca Baltasar Gracián, que contribuyó de modo decisivo al conceptismo. Y empleamos la palabra contribuir porque el conceptismo no fue una creación de esta orden ya que tal tendencia existía anteriormente. Existió, como observa Antonio Martí, una falta de visión en la cúpula dirigente de la orden $\mathrm{o}$, al menos, una situación paradójica porque si oficialmente, y así ocurría también con muchos autores jesuitas, se rechazaba todo tipo de conceptismo ${ }^{28}$, el mismo sistema de estudios retóricos promovía reproducción de esta de corriente ${ }^{29}$.

Sin duda, otro de los elementos que contribuyeron a la proliferación del barroquismo en los sermones fue el escolasticismo decadente promovido por las órdenes religiosas ${ }^{30}$. Era una tendencia natural: «...es (una) razón de carácter personal: el puesto de predicador era, con frecuencia, la culminación de una vida dedicada a la

27. Ibídem. Es muy interesante a este respecto el estudio de la polémica que se produjo en la orden ignaciana respecto a la obra de Fr. Félix Hortensio de Paravicino. Hubo dos posturas enfrentadas, encarnadas por los jesuitas José Ormaza, autor de Censura de la elocuencia, y Valentín de Céspedes. El primero, aunque reconoció «... a Fray Hortensio muy grandes dotes y le califica de gran genio», le achacó algunos vicios (CERDÁN, F.: introducción a op. cit., p. XVI). Esta oposición de Ormaza al nuevo estilo le fue censurada por el Padre Valentín de Céspedes (ibid., p. XVII). Podemos resumir la actitud de Ormaza con las siguientes palabras: «Aunque los censure, bien sabía el padre Ormaza que tales tropos gustaban al público. Sin la menor duda, este lenguaje florido y poético (característico de la oratoria sacra barroca) fue a lo largo del siglo XVII el blanco de censuras y sátiras, pero también fue el principal ingrediente que granjeó a la oratoria sagrada el aplauso del auditorio y la razón primera del éxito que conoció...» (ibid., p. XXI).

28. El propio General de la Orden Jesuita llamó al orden a Gracián.

29. Frente a las contradicciones internas que hay en la Ratio, la imitación, para los reformistas, fue un procedimiento estricto y muy riguroso donde no cabía ningún tipo de libertad, aunque sí que eran aceptables ciertas innovaciones. A esta cuestión nos hemos referido por extenso en nuestra tesis de licenciatura.

30. Esta era, en opinión de muchos tratadistas del Setecientos, «una de las causas más principales de la decadencia y corrupción de la predicación» (SÁNCHEZ VALVERDE, Antonio: El predicador, Madrid, 1782, p. 83). Este autor se refiere, concretamente, a la escolástica: «EI doctísimo Padre Juan de Mariana, hablando de los defectos que en su tiempo y en su casa se introducían en este género de estudios, y los prejuicios que de ellos se seguían, usó de una tan valiente como graciosa expresión. Los estudios escolásticos, dice, son secos y no para toda la vida, y como no entienden los Santos, ni tienen lenguas para entrar en la Escritura, deságuanse por los Sermones» (ibid., p. 83). Y Valverde concluye que: «Por estos desaguaderos de la ignorancia, y mala inteligencia de la verdadera Teología comenzó y se propagó el abuso y mientras no se estudie como se debe esta ciencia, es imposible que hagamos Sermones buenos y originales» (ibídem). 
docencia; no es, por tanto, de extrañar que estos predicadores llevasen al púlpito la erudición y la dialéctica propias de la cátedra. Como consecuencia, se abriría ante ellos una doble tentación: la sutileza del concepto o los realces del lenguaje culto» ${ }^{31}$. Unos conceptos que, si atendemos a la formación de los oradores sagrados, procedía del empleo de la escolástica.

Como hemos dicho anteriormente, los reformistas del Setecientos, y por extensión algunos de los miembros de la orden ignaciana, reaccionaron contra el enrevesamiento y la ingeniosidad de la oratoria sagrada barroquista; el escrito del padre Codorniu, que analizamos en este artículo, es una buena prueba de esta reacción.

Codorniu afirmó que la oratoria sacra, más que en el arte humano, debía basarse en la Biblia, que se constituía de este modo en una suerte de modelo retórico ${ }^{32}$. Así, cuando se refiere a las semejanzas o símiles que el predicador debe emplear en la argumentación de su discurso, dice:

«Ant. Sabéis algunas industria para el acierto de las semejanzas? Pab. Sí, y la debo a San Francisco de Sales, que es sacarlas de la Sagrada Escritura; y esto se logrará meditando sus palabras, con sumo provecho del Predicador y oyentes» ${ }^{33}$.

Podemos afirmar que Codorniu propuso que el predicador debía expresarse con sencillez ${ }^{34}$. Se puede pensar que los autores barroquistas también alardeaban de modelos de reconocida autoridad para justificar sus excesos, pero Codorniu se distancia de su actitud. En efecto, a pesar de reconocer la importancia del empleo de los recursos retóricos para cumplir con una de las funciones esenciales del discurso, delectare, afirmó explícitamente que éstos se debían utilizar con serias limitaciones, proponiendo unos procedimientos muy concretos y simples:

31. HERRERO SALGADO, F.: La oratoria sagrada española de los SS.XVI-XVII, p. 412.

32. A este respecto, es muy significativo que titule el capítulo dedicado a los tropos del siguiente modo: «algunos tropos y Figuras de la Sagrada Escritura y Santos Padres» (pp. 83 y ss.). Para más detalles se debe consultar RICO CALLADO, Francisco Luis: La reforma de la predicación en la España del siglo XVIII. Alicante, 1999, pp. 184-204).

33. CODORNIU, Antonio: El predicador evangélico breve méthodo de predicar la palabra de Dios con arte, y espiritu. Jayme Brò, Impressor. Gerona, 1740, p. 133.

34. Codorniu se aleja, en ocasiones, de los procedimientos retóricos propios de la oratoria judicial o política. Cuando se refiere a las cláusulas que componen la comparación y sus diferencias con las que conforman la semejanza, dice que en la primera «... essas clausulas han de ser casi iguales. Mas esse fuero zélese en el Foro, pero en el Templo atiéndase al fruto» (ibid., p. 135). De este modo, lo que debe preocupar al predicador es la efectividad de su discurso, para lo que se exige sencillez y claridad: « ¿Qué cosa es Estilo? Pab. Es el modo de hablar en el sermón. Ant. ¿Esse Estilo es de importancia? Pab. Indecible: porque no está el negoico del predicar en dezir mucho o poco, sino en dezir bien. Si no diezes bien, dezir maravillas será dezir poco y si dizes bien, aun dezir poco, será dezir maravillas. Ant. Pues qué tal ha de ser esse modo de dezir? Pab. Natural, claro, devoto, y con clausulas breves» (ibid., p. 282).

Hay más ejemplos de esta postura. Refiriéndose al exordio afirmó que: «... no se cansen de valde algunos Predicadores en crespar el estilo, porque ha ser liso y llano» (ibid., p. 167). 
«De ninguna manera repugna, antes se hermana muy bien la sencillez de estilo que manda el Breve Pontificio, con el decente adorno del símil vivo, del exemplo propio, y del consejo oportuno, y aun del prudente refrán, quando viniere a manos ${ }^{35}$.

Los tropos y figuras están muy limitados, ya que sólo trata por extenso el empleo del símil y hay algunas referencias a la metáfora, sólo se debían emplear para argumentar y no para embellecer:

«se ha de definir... se ha de dividir clara, y distintamente; se ha de probar con razones... y se ha de confirmar... con la perspicuidad de los símiles y experiencia de los exemplos, conforme a las leyes que dimos en los capítulos antecedentes» ${ }^{36}$.

Así pues, Codorniu estaba a favor de un estilo sencillo en el que el empleo de los tropos y de las figuras debía estar regulado y siempre en función de la argumentación. Esta toma de posición se explica, aparentemente, por una reacción contra la oratoria sagrada barroquista. Sus reflexiones a este respecto son muy similares a las contenidas en otros muchos tratados de oratoria sagrada de la época. Sus críticas, aparte de las cuestiones relacionadas con la doctrina y la enseñanza del dogma, se dirigieron especialmente contra el estilo de la oratoria decadente. En esencia, podemos afirmar que su concepción de la oratoria sagrada, fundada en la claridad y la sencillez, chocaba directamente con el método adoptado en los sermones barroquistas. En su opinión, el orador sagrado debía adoptar una postura humilde frente a la vanidad de los predicadores al uso: «porque assí quieren afectar que sus locuciones son tan estrañas del vulgo, como familiares de la Crítica» ${ }^{37}$. De este modo, los sermones barroquistas se hacían oscuros, «... la obscuridad de ciertas locuciones que por acreditarse de críticas, ni se dexan entender, ni aun a si mismas se entienden» ${ }^{38}$.

La defensa de la sencillez retórica llevó a Codorniu a sostener la importancia de los exempla que habían sido abandonados en nuestra literatura culta y, concretamente, en los sermones. Es cierto que el exemplum, que había sido uno de los procedimientos privilegiados de la predicación desde los primeros tiempos de la Iglesia cristiana, perdió importancia en la oratoria sagrada española desde el siglo XVI. Ya en el siglo XVIII fue muy notoria la falta de calado del exemplum en los sermonarios. En el caso de Francia, Robert Ricard subrayó la diferencia que existía entre la predicación clásica de los siglos XVII-XVIII, donde los Massillon, Bourdalue, etc., brillaron con gran esplendor, y la predicación misional del momento, donde los exempla eran un elemento central: «El exemplum es, sobre todo, un procedimiento de predicación popular. Ahora bien, esta predicación clásica del siglo XVII francés no es en modo alguno una predicación popular. Es una predicación destinada a los selectos, una predicación ecle-

35. Ibid., p. 168. Se refiere al Breve de Benedicto XIII «Gravissimum praedicandi munus», que toma como referencia por primera vez en ibid., p. 167.

36. Ibid., p. 154.

37. Ibid., p. 182.

38. Ibid., p. 181. 
siástica cuando se dirige al clero o a religiosas, y una predicación de corte, que se dirige al Rey y a su círculo de grandes señores, de grandes damas, de magistrados y altos funcionarios y de escritores. Añádese que esta «élite», bajo la influencia convergente del protestantismo del cartesianismo y del jansenismo -mucho más débil en España y Portugal-acepta con dificultad lo maravilloso de los exempla medievales ${ }^{39}$.

Tenemos algunos testimonios interesantes de la época. En una preceptiva traducida tempranamente en España, escrita por el ex obispo de Rodas, Antonio Abelly ${ }^{40}$, encontramos la afirmación siguiente, que es una buena prueba del ambiente que se respiraba en la Francia de principios del Setecientos:

«Tan desacreditadas están el día de oy las Historias entre los Predicadores, que se jactan de tener buen gusto, que parecen absolutamente proscriptas, y desterradas de la predicación. Si en la Corte se oyesse un Predicador, que hiziesse una relación un poco larga, y un poco patética se le tratará de Predicador de Aldea, y de contador de cuentos; con todo esso la experiencia convence, que los exemplos tienen un poder admirable, y de muchos modos ayudan al Artificio del Orador; porque en los negocios agenos ay una curiosidad natural, que excita la atención; y como también ay mayor necessidad de conciliarse la benevolencia del Auditorio al fin del sermón, que al principio, quando los entendimientos están aun despejados un exemplo ayuda mucho a templar la fatiga» ${ }^{4 !}$.

Por lo tanto, el exemplum estaba ligado a la predicación popular, es decir, la dirigida a los hombres y mujeres sencillos. Por esta razón, y debido a su lógica interna, el Barroco renunció a este procedimiento argumentativo. Sin embargo, ya en las obras de los oradores reformistas del siglo XVI el exemplum fue desplazado de la predica-

39. RICARD, R.: «Aportaciones a la historia del «exemplum» en la literatura religiosa moderna» en Estudios sobre literatura religiosa española. Ed. Gredos, Madrid, 1964, p. 209. Es interesante hacer notar que la reacción de la Iglesia se dirigió fundamentalmente contra ciertos tipos de exempla. Si consideramos que existen cuatro tipos fundamentales de exemplum:

1. «El exemplum profano (greco-latino).

2. El exemplum bíblico.

3. El relato devoto de las Vitae Patrum.

4. El exemplum moraleja, que frecuentemente es, añadiremos, de carácter maravilloso o milagroso» (ibid., p. 202).

Muchos tratadistas rechazaron los exempla profanos, es decir, «(...)de la literatura religiosa (influida) por la literatura pagana de la antigüedad, y de la secularización de la predicación», aunque este fenómeno que se produjo de modo muy marcado desde el Renacimiento no era, en absoluto, nuevo (ibid., p. 202). Por supuesto también se rechazaron las narraciones de hecho maravillosos porque, en muchas ocasiones, eran faisas.

40. Autor de la obra: Verdadero méthodo de predicar, según el espíritu de el Evangelio. Imprenta de Don Matheo de Bedmar. Madrid, 1724.

41. ABELLY, L.: Verdadero méthodo de predicar, p. 171. La defensa de los exempla como uno de los ejes fundamentales de la argumentación no es frecuente en las retóricas dieciochescas. Sin embargo, algunos autores fueron conscientes de su importancia: «Apenas hablan quatro palabras del misterio o del Santo, se entran a declamar y verter una moral verdaderamente útil e importante, pero que no se suaviza con la dulzura del exemplo, dexándose caer, digámoslo así, de repeso sobre el corazón que resiste el yugo y sacude la carga si no se le echa con arte y se le va sosegando con blandura» (SÁNCHEZ VALVERDE, A.: El predicador, p. 134). 
ción debido a que se impuso en los sermones la sobriedad, aunque existen otras razones que explican mejor su progresivo abandono en la oratoria barroquista que son:

«(..) muy distint(os), casi opuest(os), y (...) de orden estrictamente literario. En la mayor
parte de los predicadores llamados barrocos el exemplum es destronado... (por) el concep-
to predicable. Se ve en el siglo XVII multiplicarse en España, destinadas a los predicado-
res, compilaciones de conceptos predicables, análogas a aquellas compilaciones de exem-
pla que la Edad Media había visto proliferar» ${ }^{42}$.

Los exempla no desaparecieron totalmente de los sermones, es más, creemos que ocuparon un lugar de relativa importancia. Ya hemos hecho alusión a la defensa que de ellos hizo Abelly, y no podemos dudar de su persistencia en la predicación popular:

«es poco probable que los predicadores populares de los siglos XVII y XVIII que, en conjunto no entran en la misma corriente hayan renunciado a un procedimiento pedagógico tan simple, tan natural y tan eficaz. Pensamos (...) en cuanto a España, en un jesuita como el célebre $P$. Pedro de Calatayud, y sobre todo en aquellos capuchinos que veían favorablemente la campaña del P. Isla contra el «gerundismo» y entre los que debía surgir la alta figura de uno de los mayores predicadores de la época, el Beato Diego de Cádiz (...) Pero es un dominio apenas explorado aún, y por el que un investigador aislado, en el estado actual de nuestros conocimientos, no podría aventurarse sin temeridad» ${ }^{43}$.

La obra de Codorniu es, sin duda, un buen ejemplo de esta situación.

Ya hemos aludido anteriormente al peso que tienen en la obra del Padre Codorniu las semejanzas y las referencias a la realidad cotidiana. Debían ser tomadas de unos materiales o realidades muy concretos: «quanto fuere possible, de los instrumentos de su arte y exercicio (de los oyentes): del campo, de la lluvia, de las plantas, etc. con los Labradores. Ya un modo semejante con los demás. Fórmense generalmente de las cosas más conocidas» ${ }^{44}$. Pues bien, estas semejanzas son una muestra palpable, o al menos así los debe presentar el orador sagrado de que todos los procesos están dirigidos por la mano de Dios y que contribuyen a exaltar la grandeza y bondad de Dios; en definitiva se trata de ilustraciones de una regla general que es la Intervención de Dios en el mundo, ya sea material o espiritual y que se refieren metafóricamente, al menos

42. RICARD, R.: «Aportaciones a la historia del «exemplum» en la literatura religiosa moderna», p. 220.

43. Ibid., p. 223-4. Creo que a este respecto es interesante destacar que en la predicación jesuita, como en el caso del Padre Pedro Calatayud, los oradores sagrados recurrieron a los ejemplos entresacados de la realidad cotidiana o de la experiencia vital de las comunidades. Y ello hizo que «los predicadores jesuitas, sobre todo, cuyo auge va en aumento desde principios de siglo, por una tradición de la orden, nos ofrecen sermones más en consonancia con el tiempo y la circunstancia. Deriva esto, a nuestro juicio, de la eminente virtud prä́ctica y concreta de los Ejercicios ignacianos, que hace que todos los sermones, aún lleno de las galanuras de la retórica, se adscriban a fines prácticos, urgentes para el auditorio que los escucha» (SORIA ORTEGA, A.: Fr. Manuel de Guerra y la oratoria sagrada de su tiempo, p. 122).

44. CODORNIU, Antonio: El predicador evangélico..., p. 134. 
en el caso de Codorniu, al perfeccionamiento que lleva a la salvación. El florecimiento de una planta es un trasunto del mejoramiento espiritual ${ }^{45}$ :

«Christo y el Sol, ambos luz del mundo. Porque assí como por las influencias del Sol material viven, crecen y fructifican los vivientes, y plantas; assí las almas con los rayos del sol Divino Christo viven a su gracia, crecen en virtud, florecen en perfección, y fructifican en buenas obras» ${ }^{46}$.

Codorniu, al igual que otros autores de la época, tomó la Naturaleza como punto de referencia porque en ella era visible la acción de Dios ${ }^{47}$ :

«Porque todas las criaturas del mundo, cada una en su estilo, publican las glorias de su Criador... Y la Sagrada Escritura nos predican en muchas partes con exemplos y semejanzas de insensibles, vivientes y plantas» ${ }^{48}$.

No nos debe extrañar, pues, la presencia de elementos que pueden describirse como argumentos por comparación referidos a realidades cotidianas, próximas a la experiencia vital de los auditorios: «Si radix santa, et rami. Es dezir, el azebuche degenera de su bastardía y aspereza, una vez que esté ingerido en el Olivo; porque éste, alimentándole como ramo proprio, le comunica su naturaleza, su vigor, y suavidad. Pues assí los Gentiles, Pueblo estraño, y bárbaro, una vez que recibieron el Evangelio, quedaron unidos a Christo, fueron ramos de ese árbol de la vida, y miembros místicos de su cuerpo, de cuya gracia viven, florecen en virtud, y fructifican en santidad» ${ }^{49}$. Aquí tenemos, de nuevo, un buen ejemplo de cómo Codorniu toma como modelo retórico la Biblia, ya que en ella se alegan como ejemplos «y semejanzas de insensibles, vivientes, y plantas» ${ }^{50}$.

Hemos de destacar algunas referencias a los exempla que, en opinión del Padre Codorniu tienen un papel esencial en la argumentación. Alude, especialmente, a las historias de la Biblia, aunque también las «... historias profanas, como de las Monarquías, Emperadores y repúblicas de los Gentiles, y de los libros mismos Gentiles». Estos últimos elementos argumentativos deben usarse con limitaciones. Ello nos pone ante una discusión central en este siglo, la oposición entre la retórica rigurosamente sacralizada y una retórica laicizada de la que se ha dicho que los jesuitas son una buena muestra. La postura de Codorniu respecto a los exempla refleja una clara intención de

45. Ibid., p. 132.

46. Ibídem.

47. El hecho de que la Naturaleza se convierta en el punto de referencia de las ideas estéticas y retóricas de Mayans tiene una razón muy clara y es que: «la participación o intervención decisiva de Dios en la creación de la naturaleza la que le confiere en principio el grado de perfección que posee. El artista, al intentar imitar la naturaleza, se encuentra no sólo ante algo perfecto, sino ante la labor del supremo artífice, del hacedor divino» (PÉREZ MAGALLÓN, J.: En torno a las ideas literarias de Gregorio Mayans. Ed. Instituto Juan Gil-Albert, Alicante, 1992, p. 198).

48. CODORNIU, Antonio: El predicador evangélico... pp. 148-9.

49. Ibid., pp. 138 y s.. Hay más ejemplos en p. 139.

50. Ver sobre esta cuestión, ibid., p. 149. 
desterrar los elementos paganos de la predicación; en efecto, Codorniu afirmó que las fábulas, y especialmente la mitología, se contradecían con el decoro del predicador:

«Ant. ¿Finalmente de las fábulas qué sentís? Pab. ¡O Dios mío! Essas dexarlas de todo punto. Porque si no son laudables en la boca de los Comediantes, cómo lo serán en la del Predicador? ¿Quién puede sufrir ni el nombre de la impura Venus en un sermón de la más pura Virgen? $\rangle^{51}$. Y ello a pesar de que en ellos se contienen algunas verdades y consejos morales aprovechables ${ }^{52}$.

En consecuencia, la fuente de la que deben extraerse los exempla e historias debe ser la Biblia. Codorniu hace, en boca de Pablo, una apología de su uso: «¿Pues qué le falta a la Sagrada Biblia de sabiduría, y de ingenio, de magestad y hermosura, de discreción y elegancia si se estudiara con el cuydado y humildad que se debe para que se aya de acudir a Heródoto, a Luciano, a Pausanias, a Ovidio y otros artífices de la ficción y mentira? $\gg^{53}$.

51. CODORNIU, Antonio: El predicador evangélico... pp. 151 y s. El Padre José Francisco de Isla insistió en la misma cuestión en su Fr. Gerundio (BLANCO, M.: «La Critique de la prédication...», p. 167).

52. CODORNIU, Antonio: El predicador evangélico... p. 152. Lo que le responde su interlocutor no tiene desperdicio: «¿Mas quién los ha de beber por canales tan sucios? De los Padres antiguos, dize mi venerado San Francisco de Sales, que en sólo un sermón de San Ambrosio leyó la de Ulysses, y las Syrenas; y essa aun es de las más discretas, y menos peligrosas» (ibídem).

El mismo José Fco. de Isla reaccionó contra el empleo de la mitología por el orador sagrado. De este modo, en el Fr. Gerundio denunció: «... l’emploi surabondant des sources littéraires profanes et tout párticulièrement des mythes et des rites antiques. Les prédicateurs ont 1 habitude d'évoquer le calendrier des fêtes païennes à propos de la solennité liturgique qu ils commentent, ce qui les amène à tracer des parallèles entre le culte chez les Anciens et les croyances chrétiennes» (BLANCO, M.: «La Critique de la prédication...», p. 165, se pueden ver algunos buenos ejemplos de este fenómeno).

53. Ibídem p. 152. Codorniu coincidió con otros reformistas posteriores; Antonio Sánchez Valverde (El predicador. Madrid, 1782), destacó la Biblia como fuente fundamental de los exempla: «Una Oración sobre la avaricia, por exemplo, en que se dé todo su vuelo al discurso humano, se dexe correr la imaginación a buscar pinturas, imágenes, frases, para hacer aborrecible este vicio (...) una oración digo semejante, podrá convencer a una razón indiferente y clara, persuadir a un corazón libre y desapasionado, tocar y comover (sic) al mismo avaro, mientras dura el torrente de aquella eloqüencia, la vista de aquellas pinturas, y mientras está, digámoslo así en la scena mirando el espectáculo; pero apenas saldrán(...) comenzará a debilitarse la impresión, enfriarse el ánimo, a rebullir la pasión(...)

No me persuado que sucedería así, si en vez de todas aquellas imágenes y pinturas humanas se le hubieran puesto delante las divinas, que hicieron Isaías, de la ira de dios contra su Pueblo: y hablando como el Profeta, en persona del mismo Dios, manifestase que la perversidad de su avaricia era la que había movido la indignación divina(...) Jeremías: de las terribles amenazas, con que aterró el Señor al mismo Pueblo(...) Amós: del Tribunal, que tomó al Señor para fulminar contra la avaricia, poniéndose de pies sobre el aitar(...) si hubiera dicho que el mismo Jesuchisto había prevenido a sus discípulos contra este vicio, amonestándoles que tuviesen cuidado de guardarse de toda especie de avaricia(...) si hubiera manifestado con S. Pablo que esta pasión es raíz de todos los males» (SÁNCHEZ VALVERDE, A.: El predicador, pp. 61-64).

Gregorio Mayans insistió en los mismos razonamientos: «todo quanto considere que puede conducir al intento, como son sentencias, razones, comparaciones, imágenes, descripciones, semejanzas, egemplos $\mathrm{i}$, si son éstos sagrados, son más eficaces por ser infalible su verdad» (MAYANS, G: «El Orador Christiano», I, 79). 
Sin embargo, ello no supuso una renuncia absoluta a los clásicos grecolatinos o, más exactamente, a ciertos escritos y autores. En efecto, el uso de la retórica siguió teniendo como referencia a los clásicos. Pero, al igual que tantos otros preceptistas Codorniu dejó clara la necesidad de expurgar las obras de estos autores ${ }^{54}$.

Se ha dicho que la acción reformista emprendida por la orden jesuita careció de la coherencia suficiente para hacer posible lel surgimiento de una retórica sacra renovada. Las razones de esta afirmación son, en cierta medida, discutibles. Uno de los motivos esenciales a los que se refieren los autores que sostienen tal postura es la pervivencia de la escolástica en las obras de los reformistas jesuitas ${ }^{55}$. Sin embargo, podemos afirmar que tal aseveración es cierta tanto para los jesuitas como para la gran mayoría de los reformistas ${ }^{56}$. No se puede negar que este tipo de materiales siguieron siendo un elemento importante para muchos de ellos, desde Gregorio Mayans a otros autores de menor relumbrón ${ }^{57}$. Obviamente, no reaccionaron contra la escolástica en general, sino contra la verbosista, es decir, contra aquella que inducía al predicador a construir discursos sutiles. Si el orador debía conocer los fundamentos de la escolástica para poder explicar y entender correctamente el dogma y la doctrina de la Iglesia,

54. Ibid., p. 150 y especialmente p. 151.

55. SAUGNIEUX, J.: Les jansénistes espagnols et le renouveau de la prédication..., pp. 128-33.

56. Por supuesto, los jesuitas rechazaron, en muchas ocasiones tanto las novedades como las críticas al viejo sistema filosófico, es decir, fueron defensores a ultranza del escolasticismo. Sin embargo, está claro que los miembros de la orden ignaciana se interesaron por las novedades científicas, aunque siempre sosteniendo la validez del sistema aristotélico.

La actitud de los jesuitas es muy diferente de los restauradores como Mayans, término empleado con gran lucidez por SÁNCHEZ-BLANCO PARODY, Francisco: La mentalidad ilustrada. Ed. Taurus. Madrid, 1999 (para conocer su posición en profundidad se debe consultar especialmente el capítulo III de esta obra). Una buena muestra de ello es que Mayans aceptó las teorías de Vicente Tosca, que abrían la puerta al atomismo, lo que le alejó de las posiciones sostenidas por los jesuitas:

«El planteamiento de la filosofía jesuítica se diferencia del ecléctico... Los jesuitas siguieron a Suárez y rechazaron la interpreteación corpuscular d ela materia. Por otro lado, dentro de la escolástica, ellos y sus cátedras eran los «antiatomistas» de la época. La disensión crucial residía en la cuestión de si existe una diferencia real entre la esencia y existencia» (ibid., p. 180).

Por esta razón, Sánchez-Blanco sostiene que el eclecticismo de los jesuitas: «... fue más táctico y de envase que de fondo» (ibid., p. 181). Así, el hecho de que las cátedras de la Facultad de Artes la nueva universidad de Cervera estuviesen en manos de los jesuitas hizo que:

«Lo que se enseñó... no difirió esencialmente de lo que, por ejemplo, Luis Losada exponía en su cátedra salmantina, lo cual, como ya se vio, no suponía ninguna ruptura con la física aristotélica, por más que integrara dibujos y explicaciones de algunos experimentos» (ibid., p. 181).

57. Véanse sino las siguientes reflexiones de Mayans: «Supongo que el que ha de esplicar los Misterios de la Fe, ha de estar bien instruído en ella. Deve ser buen escolástico, i mejor dogmático. Pero es menester acordarse que la Escolástica es mui seca, i espinosa; i assí solo ha de escoger lo más importante, sin omitir cosa alguna por sabida que sea, como se deva saber. Muchos, pródigos del tiempo, dejan de esplicar lo que en toda la eternidad no se acabará de entender. Otros se entretienen en declarar palabras Escolásticas, que pudieran escusar, usando de otras más claras; porque decir que no las ai, es pobreza de ingenio i de lengua. Otros, acostumbrados a ellas, no las declaran, pareciéndoles, que todo el Auditorio las entiende» (MAYANS, G.: El orador christiano, citado por SAUGNIEUX, J: Les jansénistes espagnols et le renouveau de la prédication..., p. 181). 
su doctrina debía alejarse totalmente de una exposición enrevesada o rebuscada, tan propia de las cátedras de teología que tanto se parecían a nuestros púlpitos. Codorniu participó de ambos caracteres, tanto de la defensa de la formación escolástica para los predicadores como de la exigencia de una predicación llana y al alcance de los hombres y mujeres del pueblo ${ }^{58}$. En uno de los capítulos, donde se plantea cómo proponer la idea o asunto del sermón ${ }^{59}$, dice que uno de ellos es proponer «...alguna questión, no Escolástica, sino Moral, práctica y acomodada a los oyentes» ${ }^{60}$. En su obra, Codorniu deja muy claro que el predicador debe estar: «(...) a lo menos medianamente versado en la Sagrada Escritura, y Theología Escolástica, pero mucho más en la moral, principalmente en lo que toca a la naturaleza, causa, y efectos de las virtudes y vicios ${ }^{61}$.

Sin embargo, tales afirmaciones pueden ser matizadas y, como veremos, en su obra existe una clara tendencia sutil o enrevesada de claro carácter barroquista.

En cierta medida, y Codorniu es una buena prueba de ello, en nuestra preceptiva de retórica sacra del XVIII está clara la síntesis entre la teología positiva y la escolástica que ya había sido emprendida por los grandes teólogos españoles del Quinientos ${ }^{62}$.

58. En efecto, Codorniu fue uno de los adalides de la escolástica: «Los jesuitas Antonio Codorniu y Pedro Calatayud se constituyen en defensores de la auténtica «crítica» y del «buen gusto» contra los que en España se expresan con demasiada libertad y nos respetan ninguna autoridad. Ambos pretenden frenar la ola de «criticismo» que invade el país exigiendo mayor obediencia al magisterio de la Fe» (SÁNCHEZ-BLANCO PARODY, Francisco: La mentalidad..., p. 300).

59. CODORNIU, Antonio: El predicador evangélico...: Capítulo VII, pp. 37 y ss.

60. Ibid, p. 38. En efecto, los sermones de los jesuitas parecen haber estar centrados más en la realidad cotidiana que en la discusión de problemas trascendentales:

«los predicadores jesuitas, sobre todo, cuyo auge va en aumento desde principios de siglo, por una tradición de la orden, nos ofrecen sermones más en consonancia con el tiempo y la circunstancia. Deriva esto, a nuestro juicio, de la eminente virtud práctica y concreta de los Ejercicios ignacianos, que hace que todos los sermones, aún lleno de las galanuras de la retórica, se adscriban a fines prácticos, urgentes para el auditorio que los escucha» (SORIA ORTEGA, A.:El maestro Fr. Manuel de Guerra y la oratoria sagrada de su tiempo. Ed. Universidad de Granada. Granada, 1991, p. 122).

Si consideramos que los miembros de la orden ignaciana estuvieron estrechamente ligados a las misiones interiores, podremos entrever claramente que, debido a la estrecha relación entre púlpito y confesionario, los sermones jesuitas se basaban en la exposición de casos de conciencia o de situaciones; este método tenía como objetivo hacer referencias directas a los miembros de la comunidad para transformar sus comportamientos o dirigir sus actuaciones en un sentido ajustado al dogma.

61. CODORNIU, Antonio: El predicador evangélico..., p. 184. Es decir, de toda una serie de distinciones y casos que son tratados desde un punto de vista escolástico, pese a que en el fragmento citado se diferencien de la Escolática.

62. En realidad, creo que no hay que entender este recurso a la escolástica como una renuncia a otras corrientes como la teología positiva introducida por los humanistas: Erasmo, Vives, etc y que estos contraponían a la escolástica verbosista. Es cierto que los humanistas reaccionaron contra la escolástica por su exceso de sutilidad, ya que para ellos lo fundamental era volver a las fuentes, a la palabra de Dios. Sin embargo, sus obras carecieron de una formación teológica rigurosa. Nuestros teólogos del Quinientos hicieron una síntesis entre lo mejor de ambas corrientes: «ante todo la novedad más importante fue la creación de un Nuevo Método teológico caracterizado por el sano equilibrio entre Teología 
Codorniu, un personaje con clara formación escolástica, propuso que la Biblia debía ser el motivo central de la predicación ${ }^{63}$. Es más, al igual que Mayans y otros protagonistas de la reforma de la predicación, subrayó la necesidad de retornar a la Biblia e imponer una buena formación a los predicadores en este aspecto.

Debemos hacer notar que la Biblia es un texto oscuro y que, por lo tanto, necesita de un estudio profundo para ser comprendida adecuadamente. Por esta razón, los tratados de predicación se convirtieron en manuales de exégesis bíblica. A esta materia dedican un espacio destacado muchas preceptivas de la época y la de Codorniu no es una excepción en este aspecto.

Podemos concluir, tras el análisis de estos escritos, que los preceptistas de la época se opusieron a la libre interpretación de las Sagradas Escrituras. Es más, la explicación ajustada de la Biblia dependía de las autoridades ${ }^{64}$ : «También son reprehensibles aquellos, que la quieren entender, y explicar, sin la segura guía, y clara luz de los Santos Padres, y Sagrados Interpretes; por el peligro a que se exponen de torcer sus sentidos» ${ }^{65}$.

De este modo, el predicador no debía desvelar los sentidos desconocidos de la Biblia, sino transmitir ${ }^{66} \ll(\ldots)$ aquel sentido se ha de tener por verdadero, que por toda la Iglesia está recibido ${ }^{67}$.

El empleo de las autoridades permitía influir en el auditorio al tiempo que impedía que el orador buscase la ingeniosidad o las afirmaciones novedosas. Su importancia fue tal que autores como Codorniu incluyeron en sus obras una clasificación de

positiva y teología Especulativa. Era una Teología Positiva que tenía muy en cuenta aquel grito de los humanistas: ad fontes!, de ahí el amplio manejo de las fuentes y la erudición que la caracteriza: la Sagrada Escritura, los Santos Padres, documentación conciliar y pontificia, etc. Pero al mismo tiempo era también una teología Especulativa, esto es científica, deductiva: a la razón se le reconoce un papel en la tarea teológica: ni se exagera (como la sofística y el verbosismo de la escolástica decadente), ni se suprime (como Lutero y algunos humanistas). En la Escuela de Salamanca tanto el aspecto positivo como el especulativo encontraron un desarrollo armónico y equilibrado» (BELDA PLANS, Juan: «Domingo de Soto (1495-1560) y la reforma de la Teología en el siglo XVI» en Anales Valentinos, $\mathrm{n}^{\circ}$ 42, 1995, pp. 199-200).

63. «Ant. ¿Qué cosa es predicar?. Pab. Es persuadir lo que contiene el Evangelio, o disuadir de sus contrarios» (CODORNIU, Antonio: El predicador evangélico, p. 8).

64. En la obra de Codorniu, la autoridad se destaca como un argumento de gran importancia y efectividad, «en nuestro caso (la autoridad) es un dicho, o proposición sabia, ponderosa, y eminente, que se haze cierta, o muy verisímil, por la ciencia, y bondad, que suponemoș en quien la dize» (CODORNIU, Antonio: El predicador evangélico..., p. 144).

65. CODORNIU, Antonio: El predicador evangélico..., p. 114. AQUINO, Nicolas de: El púlpito o reflexiones útiles a los jóvenes eclesiásticos, que se dedican al santo ministerio de la predicación evangéli$c a$, Madrid, 1788 dice que «(...) la lección de los Padres y Predicadores famosos. Ellos son las fuentes puras de la Moral de JesuChristo: la llave de oro, para facilitarnos el tesoro de las Escrituras Sagradas. Sin estas guías no iremos seguros por los espaciosos campos de la escritura: y se nos obscurecerán muchas de sus verdades sublimes» (pp. $44 \mathrm{y} \mathrm{s}$ ).

66. BENAVIDES DE SANTA MARÍA, Bruno: Directorio del púlpito rústico a Fabio. Imprenta de Rafael Figuró. Barcelona, 1713, pp. 92 y s.

67. Ibid., p. 94. 
éstas: «Supuestas en primer lugar como primeras, e irrefragables, las Divinas, y Eclesiásticas, que insinuamos en el capitulo II ${ }^{68}$. Usará en segundo lugar de la authoridad de los Santos Padres, y de los Doctores Cathólicos; pues unos, y otros son arroyós derivados, mas, por menos caudalosamente de la verdad $»^{69}$.

Debemos subrayar la presencia de ciertas ambiguiedades en la obra de Codorniu. Se trata, fundamentalmente, del hecho de que el jesuita propone como modelos para los predicadores autores barrocos como el portugués Vieira, perteneciente también a la orden ignaciana y que no es censurado en ningún momento ${ }^{70}$. En cierta medida, la propuesta de Vieira como modelo condujo a que Codorniu sostuviese afirmaciones paradójicas y que lo asimilan a los hábitos del barroquismo. Hay algunos ejemplos interesantes de este fenómeno. Así, sugiere como modelo un sermón de Vieira sobre San Ignacio en el que la proposición central era que este santo era «El semejante sin semejante $\gg^{71}$. En otras ocasiones, aparecen consejos que apuntan al empleo masivo de antítesis, habitual en los sermones barroquistas y tan criticado por los reformistas:

«...San Francisco de Borja... Esse Santo, nobilíssimo de sangre, y opulentíssimo en los bienes que llaman de fortuna, lo dexó todo por ser humilde siervo de Christo... Pues ya despunta el dedo del gigante ya se descubre la profundíssima humildad de Borja. Dexóse también a sî mismo... Pero como en esto de dexarse a sí mismo también cabe más y menos, ¿quanto se dexó? Se dexó hasta anonadarse... substituyendo a la grandeza y elevación de señor, el abatimiento y baxeza de siervo» ${ }^{72}$.

68. Hablando sobre los lugares de los que se podían extraer argumentos: «(...) singularmente de los Tehológicos(sic), de los quáles: El primero es la Sagrada Escritura, por la authoridad de Dios, que siendo infinitamente Sabio, Veraz, y Bueno, no puede engañarse, ni puede engañarnos. A essa Escritura llama San Pablo, Arma militie nostrae, y de ellas, en primer lugar, se debe armar el Predicador» (CODORNIU, Antonio: El predicador evangélico..., p. 104)

«El segundo lugar son las Tradiciones Universales, pertenecientes ya a la Fe, ya a las buenas costumbres, porque son derivadas de la boca de Christo, o dictadas del Espíritu Santo, y conservadas en la Iglesia Cathólica con continua successión. Assí lo difine el concilio de Trento» (Ibid., p. 105)

«El tercero, la authoridad de la Iglesia Cathólica, de la qual dize San Pablo: Est Ecclesia Dei vivi columna, et firmamentum vertiatis» (ibid., p. 106).

El cuarto, sobre el que tendrian dudas algunos preceptistas sería: «la authoridad del Sumo Pontífice: porque a San Pedro, y en él a todos sus legítimos Successores dixo Christo: Ego rogavi pro te, ut non deficiat fides tua: et tu aliquando conversus confirma fratres tuos» (ibid., p. 106). Aunque también descuidar de los fieles «Pasce agnos meos: Pasce oves meas» (loan 21). En último lugar los Concilios Ecuménicos siempre que sean «legítimamente congregados» (ibid., p. 106)

69. Ibid., p. 145.

70. Incluso, Codorniu le dedica un amplio espacio en uno de los capítulos de su obra (concretamente en el capítulo XII, pp. 99-104, donde dice que es único, esto es el maestro de maestros). Lo cierto es que esta valoración de la obra del portugués choca la ausencia total de referencias a los grandes autores franceses que estarán presentes en las retóricas posteriores. ¿Se puede atribuir a una falta de calado de estas obras en ciertos sectores de la España de principios del siglo XVIII? Esta es una cuestión que sólo futuros estudios pueden esclarecer plenamente.

71. CODORNIU, Antonio: El predicador evangélico..., p. 76.

72. Ibid., p. 85. En la página siguiente aparecen nuevas propuestas conceptuales para el sermón el mismo panegírico y se sugieren los métodos empleados por Vieira en su sermón Xavier Dormido y Dispierto (sic). 


\section{Estas sugerencias contrastan o son matizadas después por Codorniu:}

«Esta Figura (la antítesis) es también demasiadamente lisongera del gusto: y assí póngase cuydado en la parsimonia, y oportunidad. No sea, que el sermón parezca tablero de axedrez, y que no se hallen dos palabras en paz, como con sentida agudeza nota Vieyras ${ }^{73}$.

Podemos afirmar que la reforma de la predicación emprendida por Codorniu careció de algunos de los caracteres esenciales de la corriente rigorista. Entre ellos podemos destacar la ausencia de la meditación y de la oración en la acción del predicador, por lo que sus discursos debían basarse fundamentalmente en la sabiduría, el dominio de la palabra de Dios -las Escrituras y por supuesto las autoridades de la Iglesia para comprenderla con precisión-y, finalmente, un uso ajustado de la retórica ${ }^{74}$. En consecuencia, la tarea del predicador, exigía una panoplia de virtudes: «...sus fuerzas, su doctrina, su voz, su estilo, su gracia, y las prendas de alma, y cuerpo, que requiere el Púlpito ${ }^{75}$. Es notable, sin embargo, que el jesuita subraye, sobre todo, la humildad ${ }^{76}$.

En su opinión, predicar es, coincidiendo así con las opiniones sostenidas por otros muchos preceptistas, «...persuadir lo que contiene el Evangelio, o dissuadir de

73. Ibid., p. 89. Hay que hacer notar que el empleo del lenguaje paradójico, contradictorio, etc. era un hábito muy común en las composiciones barrocas en las que, en ocasiones, se producían constantes claroscuros. Esta idea del ajedrez no es nueva; el tratadista B. de Salazar afirmó que: «No podemos, en llegando a aqueste punto, dexar de traer a la memoria aquel exemplo tan vulgar, y tan común, como repetido en los púlpitos del juego de Axedrez, si bien siempre provechoso, y ajustado para el caso (que al fin, como los muevan, a veces desengañan y aprovechan mas a los oyentes, que las agudezas mayores) aún bien que los jueguen muchos, y conocerán lo que es: Compónesse de Reyes, Roques, Arfiles, de Damas, y de Peones. Mientras el tal juego dura, respétase cada pieça conforme el oficio que haze: Con que veneración se trata al Rey; cómo lo defienden todos; cómo persiguen al que le quiere dar mate; con qué libertad corre el Roque; con qué ligereza cruza por donde quiere la Dama; cómo reconoce sus calles el Arfil; cómo obedece el peón; cómo brinca el caballo; cómo se guardan unos a otros sus fueros; pero en concluyendo con el juego, la misma estimación hacemos de una pieça, que de otra, del Rey que del peón, de la dama que del Roque, ni ay Rey ni Roque que valga: todos van a una sepultura; esto es, a una taleguilla donde se guardan las pieças» (citado en CARO BAROJA, Julio: Las formas complejas de la vida religiosa. Ed. Sarpe. Madrid, 1985, p. 223).

74. Respecto a las que, en opinión de Codorniu, son las cualidades fundamentales del predicador, dice Saugnieux que: «Pour ce qui est de la forma, ou qualités acquises: une vie exemplaire, une science solide et un certain talent artistique (destreza de arte). Le prédicateur doit être savant puisqu il est à la fois le maître et le médecin des âmes» (SAUGNIEUX, J.: Les jansénistes espagnols et le renouveau de la prédication..., p. 93). Véanse en esta página los conocimientos que exige Antonio Codorniu al predicador.

75. CODORNIU, Antonio: El predicador evangélico..., p. 6.

76. Con afirmaciones muy semejantes a las contenidas en otros muchos tratados de oratoria sagrada de la época como: «El que tuviere talento, y vocación de Dios» (ibid., p. 5) o que el predicador es un enviado de Dios, lo que le servirá para triunfar en su empresa: «Acuérdese que le embía Dios: Ecce ego mitto vos. Yo te embío, dize Dios, y basta que te embíe y para que emprendas gustoso la misión» (ibid., p. 6). Lo que si bien supone por un lado una tarea honrosa, también implica, por otro, unas obligaciones claras que diferencian claramente al predicador tal y como lo entiende Codorniu de las desviaciones barroquistas. 
sus contrarios» ${ }^{77}$; ello supuso una revalorización del papel de las Sagradas Escrituras como motivo central, aunque no único, de la predicación, ya que la escolática siguió teniendo una enorme importancia en la labor del orador. Baste decir que en ello coincidió el jesuita con autores alejados de su visión del hombre y de la predicación.

Esta labor de persuasión o de disuasión se basaba, sobre todo, en el empleo de las razones ${ }^{78}$, por lo que los medios humanos parecían anteponerse a la inspiración divina que, para Mayans y otros, era un componente esencial de la predicación y que se conseguía a través de la oración y meditación ${ }^{79}$. Sin embargo, como en el caso de los simpatizantes del jansenismo, Codorniu concluía que la moción actual era «don de Dios, y elección de la voluntad del oyente; y ni una cosa, ni otra está en mano del Predicador» ${ }^{80}$. De este modo, podemos concluir que la intervención de la gracia divina jugaba un papel de gran importancia tanto en las obras de los rigoristas como en la de este jesuita. ${ }^{81}$ Pese a la importancia de la acción de Dios, uno de los matices que

77. Ibid, p. 8. Para predicar el Evangelio, este autor adoptó un método específico que coincide con el propuesto por autores como Gregorio Mayans y que supuso el abandono de las apostillas de la Biblia: «Pues no se podrá exponer todo el Evangelio que se lee, echando allá un discurso, y acullá otro? Porque assí parece mas bello el Sermón. Pab. Esso no es Sermón, sino postilla, y es bueno para comentario, mas no para el Púlpito: ni es por esso el Sermón mas hermoso, sino más feo» (ibid., p. 30).

78. Si hemos dicho anteriormente que la labor fundamental del predicador es dissaudir o persuadir, según Codorniu, dissuadir es «instruir el entendimiento de los oyentes con razones, que muevan la volunta a huir, o enmendarse de alguna determinada acción. Ant. ¿Qué quiere dezir con razones? Pab. Fuerza y valentía de argumentos, con gravedad de sentencias, fervor de afectos, selecto y peso de palabras» (ibid., p. 8).

79. «El modo más seguro de hallar las verdades es acudir a Dios que es la misma verdad. Ore, pues, el que quiere predicar. Si uno ora para estar en mayor contacto con Dios, perorará con los hombres. El que no se diere a la oración nada pensará con fervor, nada dirá con eficacia. Podrá la vanidad incitar a decir con aplauso, pero no con fruto. Admirará a los necios, le despreciarán los cuerdos, se indignarán los celosos, se reirán los demonios, se irritará el mismo Dios. Para que esto no suceda conviene tener oración. Con ella se concibe un gran candor y espíritu, el cual después se comunica a los oyentes. Testigos son de esta importantísima verdad los mayores oradores que ha tenido el cristianismo, los cuales todos dicen, a una voz, que vale más un rato de oración que muchas oras de estudio» (Mayans citado por MESTRE, A.: El mundo intelectual de Mayans. Ed. Ayuntamiento de Oliva, Valencia 1978, pp. 290-1).

Compárense estas reflexiones con las de Felipe Bertrán: «Semejantes Ministros Evangélicos podrán consumir los días y las noches en la composición y adorno de sus Sermones; llenarlos de la más alta y sublime doctrina y de agudas y exquisitas sentencias; agotar las reglas del arte en los discursos, en la expresión, en la acción, en la hermosura de las cláusulas, en la cultura y primor del estilo: pero si sus obras no concuerdan con lo que dicen, y no hacen lo que enseñanan, todo este grande aparato no será más que un árbol pomposo(...)» (citado en BALDAQUÍ Y ESCANDELL, Ramón: «La reforma de la predicación en el XVIII valenciano: Leonardo Soler de Cornellá», pp. 130-1). En consecuencia: «La virtud y espíritu de Dios conmueve más los ánimos que toda la eloquencia humana» (citado en ibid., p. 131).

80. CODORNIU, Antonio: El predicador.., p. 9.

81. Están muy claras las coincidencias entre los jesuitas, a los que se califica, errónenamente, como laxistas. A ello aluden, entre otros APPOLIS, E.: Les jansénistes espagnols. Ed. SOBODI. Bourdeaux, 1966, dice sobre la aceptación del probabilismo en las filas de los jesuitas que: «Le géneral lutte avec énergie pour faire accepter le probabiliorisme par la Compagnie. En 1702, il va jusqu'à adresser à Clément XI une supplique, pour prier de sauver l’Ordre de la ruine qu'il se prépare. 
diferencia a ambos autores es la importancia que tiene la acción humana en la labor del predicador. De cualquier forma, podemos decir que ambas corrientes se interrelacionan en más de un aspecto; por ejemplo, Mayans dice que: «El favor de Dios no excluye la acción de la Criatura: i assí el Orador no sólo debe implorar ayuda sino que de su parte ha de hacer todo lo que naturalmente pueda para promover la gloria de Dios. I éste es el más seguro medio de lograr su asistencia» ${ }^{82}$. La diferencia más importante es, quizá, dónde se pone el acento.

\section{CODORNIU Y LA REFORMA DE LA RELIGIOSIDAD}

Codorniu participó, como dijimos, de los rasgos más importantes de las preceptivas retóricas reformistas de esta centuria y uno de los más interesantes fue su reacción contra la religiosidad supersticiosa. Al igual que en otros tratadistas de la época, este carácter se hace muy notorio en sus referencias a los panegíricos o sermones de santos.

Hemos de considerar, en primer lugar, los caracteres esenciales de la religiosidad que pretendía desarraigar el jesuita. Para ello, debemos hacer algunas referencias a la importancia del milagro en la religiosidad popular de la época.

La religión contra la que lucharon los reformistas del siglo XVIII estaba basada entre otras cosas, en las devociones exteriores, los falsos milagros y un culto sin mesura de los santos. Las afirmaciones de los tratadistas demuestran que los púlpitos se convirtieron, a menudo, en promotores de una religiosidad que ha venido a ser calificada, simplistamente, como barroca. Por supuesto, el nuevo modelo de predicación intentó implantar un nuevo tipo de religiosidad.

El milagro es uno de los fundamentos del catolicismo junto con la autoridad y el misterio; en efecto, se asentó ya en el siglo VI como uno de los componentes esenciales de la literatura hagiográfica ${ }^{83}$. Pero lo que nos interesa especialmente, más allá de la importancia del milagro en el dogma o en la vivencia de la fe, es que se convirtió en un elemento esencial de la religiosidad popular. El hecho de que estuviese presente, la intervención de los santos en la vida de los hombres, realizando prodigios para solucionar sus problemas, enfermedades, etc. ${ }^{84}$, explica el calado que tuvo el milagro

Cette attitude déchaîne parmi ses confrères une insurrection, peut-être unique dans l'histoire de cette Compagnie si disciplinée. Mais il faut souligner que les tendances de González sont alors partagées par d'autres jésuites espagnols»(p. 39). Véase sobre la misma cuestión la nota 1 de p. 39.

Sobre la aceptación o no del molinismo dentro de la misma orden jesuita, dice Appolis que: «En réalité les exceptions sont nombreuses. Celle du géneral Tirso González est une des plus caractéristiques».

Afirmar lo mismo respecto a los rigoristas también es cierto. Como ha hecho notar Antonio Mestre, Felipe Bertrán asumió posturas laxistas.

82. Citado por SAUGNIEUX, J. Les jansénistes et le renouveau de la prédication (...), pp. 179.

83. MUÑOZ FERNÁNDEZ, Ángela: «El milagro como testimonio histórico. Propuesta de una metodología para el estudio de la religiosidad popular». En ÁLVAREZ SANTALÓ, León Carlos/ AGUDO TORRICO, J. (eds lit.): La religiosidad popular. Barcelona. Ed Anthropos, 1989.Tomo I, p. 169 y ss.

84. Ibid., p. 173. Es lo que sucede con Santa Isabel de Portugal, a la que se recurría en casos de sequías y epidemias aunque después se pensó que podía intervenir en la cura de hernias en adultos y niños. Un aspecto interesante es que el culto a esta santa surgió en las ciudades y, en concreto, en la de Coim- 
en una sociedad que intentaba buscar ciertas seguridades y auxilios. De este modo, el milagro se asociaba estrechamente a la religiosidad popular debido a las «(...) necesidades de protección, sostén y ayuda» ${ }^{85}$. Esta práctica devino, en muchas ocasiones, un culto supersticioso:

«Cualquier perturbación de la vida económica, o, simplemente, del curso natural de la existencia, provoca inmediatamente, una réplica religiosa: inundaciones o sequía prolongada, plagas de langosta, granizo, hambre, epidemias, desencadena un ciclo de procesiones o de rogativas, de ceremonias conjuratorias o expiatorias que el término de la desgracia pública convertía en manifestaciones propiciatorias. La concepción providencialista de la sociedad se afirma ya desde ese momento» ${ }^{86}$. El medio era hacer una expiación y por supuesto a la búsqueda de los mejores intermediarios ${ }^{87}$.

Y este tipo de elementos siguieron presentes en la sociedad dieciochesca ${ }^{88}$.

De este modo, la «(...) prière n'est pas une prière d'adoration et se réduit souvent à un simple marchandage avec la divinité qui doit assurer un certain lot de bonheur contre un certain degré de vertu. Il n'y a guère de gratuité dans les rapports avec Dieu» ${ }^{89}$. Así, tenemos que «les saints, et surtout les saints guérisseurs, continuent de jouer un rôle important, que Fr. Lebrun a analysé en Anjou et en Bretagne. Dans la croyance commune, chaque saint guérisseur a le pouvoir de provoquer une maladie déterminée, qui souvent porte son nom et que seul il peut guérir, la Vierge seule faisant office de généraliste» ${ }^{90}$.

El santo ocupó un lugar central en este tipo de culto porque era el agente de los prodigios. Se produjeron, de este modo, varios fenómenos de gran interés: por un lado, la especialización de los $\operatorname{santos}^{91}$, y por otro, la asociación temprana de un santo a una comunidad ${ }^{92}$.

bra lo que nos ayuda a deducir que las similitudes del culto de los santos en el medio rural y la urbe son muchas. En esta ciudad se dieron dos tendencias, por un lado, la de la adoración de esta santa fue fundamentalmente femenina ya que los hombres rendían culto, en su mayoría, a los santos Mártires de Marruecos.

85. MUÑOZ FERNÁNDEZ, ÁNGELA: «El milagro como testimonio histórico (...)», p. 170

86. BENNASSAR, B.: Los españoles, actitudes y mentalidad entre los S.XVI y XIX. Ed. La Torre Botica, Madrid, 1981, p. 66.

87. Ibid., pp. 66 y s.

88. «las calamidades colectivas fueron productoras generosas de sermones de rogativas, ya lo fueran de súplica para aplacar la ira de Dios, ya gratulatorias por haberse librado de sus azotes, tal como sucedió en uno de los ciclos más fecundos: el propiciado por el terremoto de Lisboa de 1755» (EGIDO, Teófanes: «Religión» en AGUILAR PIÑAL,Fco. (ed): Historia literaria de la España del S.XVIII. Ed. Trotta. Madrid, 1997, p. 762).

89. LOUPÈS, Philippe: La vie religieuse en France au XVIII(e) siècle. Ed. Sedes. París, 1993, p. 110.

90. Ibid., p. 112.

91. AGUILAR PIÑAL, F. «Predicación y mentalidad popular en la Andalucía del siglo XVIII» en ÁlVAREZ SANTALÓ, León Carlos / AGUDO TORRICO, J. (eds. lit.): La religiosidad popular. Tomo II. Barcelona. Ed Anthropos, 1989, p. 67, refiere algunos casos interesantes: «Los vinateros de Málaga ofrecían un culto anual a San Gregorio Ostiense «para que defienda las viñas y demás frutos (...) de la langosta, oruga, pulgón y otras especies de insectos» (ibid., p. 59). 
Hay dos consecuencias claras de esta actitud que explican algunos de los elementos más sangrantes de la religiosidad supersticiosa. En primer lugar, podemos hacer notar que los santos se convirtieron, en la concepción de muchos hombres, autores y no agentes de los milagros; de este modo, el santo se alejó de la fuente de todo este tipo de bienes: Dios ${ }^{93}$. La explicación de este papel protagonista que adquirieron los santos en la religiosidad popular es sencilla: el Dios de los cristianos se había convertido, hasta cierto punto, en un deus otiosus ${ }^{94}$, es decir, «la Divinidad suprema, que se ha ido alejando más y más de sus fieles adoradores, de sus vidas, sus luchas, sus alegrías y sus penas, a causa de un encumbramiento aberrante. Entonces empieza a convertirse en algo remoto y tan elevado que resulta irreal e inútil» ${ }^{95}$.

Este tipo de culto, que implica la presencia de elementos mágicos, provocó las críticas de los reformistas del siglo XVIII ${ }^{96}$. En esta reacción contra la concepción de los santos como cuasi-dioses destacó también el jesuita Codorniu para quien el Santo estaba en deuda con Dios y sus bienes y virtudes se debían, en gran medida, a Dios ${ }^{97}$. Buena prueba de ello son sus críticas contra el lenguaje hiperbólico empleado por los predicadores. Por esta razón no es extraño que sus reflexiones sobre los sermones de santos, que tienen como objetivo «emendar (sic) algunos Panegíricos» ${ }^{98}$, se abran con la siguiente advertencia:

92. Este tipo de adoración permitió que a partir del S.X se desarrollase el culto de toda una serie de santos locales que devinieron «protectores de un terruño, una aldea, un lugar particular, cuyas gentes ponen en ellos una confianza ingenua y aun supersticiosa» (MALDONADO, L.: Introducción a la religiosidad popular. Madrid, 1985, p. 65). Pese a que algunos santos menores adquieren posteriormente una gran notoriedad, que hará que se les rinda culto en amplias zonas, produciéndose peregrinaciones masivas, etc. no cambia en nada el concepto que se pueda tener de lo que diremos a continuación.

93. Este fenómeno se produjo en toda la Europa de la época: «Trop souvent le saint thérapeute est invoqué moins comme un médiateur que comme l'artisan même de la guérison éventuelle et la façon de s'adresser à lui relève autant de la magie que de la religion.» (LOUPÈS, Philippe: La vie religieuse en France au XVIII(e) siècle. Ed Sedes. París, 1993, p. 112). En la obra de Codorniu hay algunos fragmentos que apuntan la necesidad de superar tales ideas que se parecen haber sido frecuentes entre los predicadores de la época: «Advierta el Predicador que alabe... en el Santo a Dios. Tome por idea los Panegíricos del Ecclesiástico. Sírvanle de exemplar más proprio los de Christo, singularmente el que hizo en alabanza del Bautista. Vea y estudie en el mismo Ecclesiástico que toda alabanza y acción de gracias es de Dios, y aprenderá prácticamente las leyes más sagradas de la Peroración» (CODORNIU, Antonio: El predicador evangélico..., p. 49).

94. Concepto que se debe a Mircea Eliade.

95. MALDONADO, L.: Introducción a la religiosidad popular. lbid., p. 66.

96. «IIs (los reformistas) se plaignent de la prépondérance qui semble donnée au culte de la Vierge et des Saints sur celui de Dieu le Père et du Christ, l'unique Médiateur. Ils ne veulent pas qu'on confonde les intercesseurs, utiles, mais non nécessaires, et le Médiateur indispensable. Ils combattent la trop grande crédulité en face de légendes ou de miracles contestables. Aussi se prononcent-ils pour une histoire ecclésiastique libre et sincère, non seulement par amour pour la vérité, mais aussi dans l'intérêt bien compris de l'Église». Como ya se sabe se trata de los de los «(...) bénedictins de Saint-Maur -avec Mabillon et Montfaucon-» (APPOLIS, E.: Les jansénistes espagnols, p. 24).

97. «Qué mercedes y favores recibió de Dios, por los quales se conoce el valimeinto que tuvo con su Divina magestad. Y con qué genero de trabajos le purificó el Señor y afinó sus virtudes» (CODORNIU, Antonio: El predicador evangélico..., p. 74).

98. CODORNIU, Antonio: El predicador evangélico..., p. 46. 
«Alabanzas ay que por grosseras o desmedidas son ostentosas. Aun Alexandro, Príncipe de más ambición, que Reynos llevó tan mal el hypérbole de un Panegírico en aplauso de sus hazañas que después de averlo leído, le arrojó a un río... ¿Tanta sal, moderación y cautela pide el alabar a un gentil, pues quanta mayor a $\operatorname{los}$ Santos? ${ }^{99}$.

Es más, el jesuita dice que: «Todos los Santos son Grandes de la Corte del Cielo; en todos es maravilloso Dios y adorable su gracia. Cada uno parece el mayor pero se goza de tener en la Gloria superior o igual. ¡Felicíssima condición! ${ }^{100}$.

Quizá se deba a esta razón el hecho de que preceptistas de principios de siglo como Juan de Ascargorta insistiesen tanto en que sólo en Dios se encontraba todo bien: «toda Sabiduría, todo poder, toda Bondad, toda Justicia: y por fin todo lo que es bueno y perfecto» ${ }^{101}$.

De cualquier modo, en opinión de Antonio Codorniu, la argumentación a través de la comparación debía ser muy mesurada para evitar desviaciones. A esta cuestión dedica un amplio espacio del capítulo sobre los panegíricos. En la medida de lo posible, los predicadores debían omitir las referencias a los actos de Cristo ${ }^{102}$. No se podía deducir «... absolutamente la ventaja de Santo a Santo porque escrito está: Spirituum pondeator est Dominus. Sino de acción a acción» ${ }^{103}$, y siempre de un modo muy matizado: «... aun entonces fuera bueno modificar la consequencia con la palabra parece u otra semejante» ${ }^{104}$. Finalmente, este tipo de valoraciones debían ser razonables y oportunas $^{105}$, lo que deja muy claro el jesuita en los títulos 2 y 6 del capítulo IV, dedicado a las Reglas para la comparación ${ }^{106}$.

99. Ibid., p. 47, insiste en la misma idea en la p. 54. Buena prueba de este tipo de abusos son otras afirmaciones más explícitas que hace el jesuita en su obra: «Es posible que no ha de aver Santo que no sea muy superior a las primeras lumbreras de la Iglesia y con quien no puedan entrar en cotejo San Pedro, y San Pablo, y lo que causa más horror, el mismo Cristo, sin quedar vencidos?» (ibid., p. 55). Por esta razón se exige una absoluta fidelidad a la verdad que no es otra que: «En el reyno de los cielos todos son en sí grandes; y la Sagrada Escritura les llama Príncipes y aun Reyes. Pero respectivamente unos son verdaderamente grandes, otros menores, otros mayores y otros mínimos, términos con que se explica el mismo Christo en el Evangelio. Y porque todos viven en la región más pura de la verdad, no quieren parecer más delante de los hombres de lo que son delante de Dios» (ibid., p. 54).

100. CODORNIU, Antonio: El predicador evangélico..., p. 47.

101. ASCARGORTA, Fr. Juan de: El nuevo predicador instruido. Imprenta de Nicolás Prieto. Granada, 1716, p. 67.

102. CODORNIU, Antonio: El predicador evangélico..., p. 58.

103. Ibid., p. 59

104. Ibídem.

105. Emplea este término en p. 59.

106. (2) «Sea la comparación tan del caso com se viene a la mano y no traída por fuerza, aunque naturalmente se resista» (ibid., p. 58).

(3) «Quando sea oportuna la comparación, pórtese de suerte el Predicador que los textos queden sin quexa, la devoción sin embidia, con veneración el assumpto, los oyentes con piedad y todo con edificación y decoro». Las últimas afirmaciones de esta propuesta son de extraordinario interés y coinciden con las posiciones sostenidas por tantos otros reformistas de la predicación, opuestos a la oratoria sagrada barroquista, que pretendieron primar la enseñanza moral, es decir, hacer que los sermones fuesen útiles. 
Así pues, una de las fuentes más importantes de errores doctrinales fue la comparación de unos santos con otros con el fin de alabar al patrón de la comunidad que se predicaba. Los oradores sagrados caían, de este modo, en afirmaciones falsas. La razón era que, en un intento de alimentar la vanidad del grupo que había encargado el sermón, el orador sagrado inventaba milagros para engrandecer la figura del santo en cuestión. Por esta razón, autores como el Padre Codorniu exigieron el máximo rigor en el empleo de pruebas para conformar las proposiciones y la argumentación del sermón predicado. Codorniu subrayó que los contenidos del sermón debían ser verdaderos, lo que afecta muy especialmente al panegírico. Codorniu recomendó, en general, que: «la idea o propuesta del Panegírico sea según la copia y solidez de materiales que tuviéremos para la prueba. Si el tiro no se mide con la fuerza del brazo quedará vergonzosamente lexos del blanco» ${ }^{107}$.

Y aludía a la imposibilidad de que muchos oradores alcanzasen el dominio y la facundia de un Vieira, cuyo magisterio estuvo basado siempre en «aquel milagroso conocimiento de las Sagradas Escrituras» ${ }^{108}$. En efecto, la erudición que empleaba el orador en la composición de los sermones debía estar basada siempre en las autoridades, es decir, sus pruebas y argumentos debían ajustarse estrictamente a lo que la Iglesia consideraba verdadero.

La misma preocupación transmiten otras muchas preceptivas del siglo XVIII. En opinión de Mayans, los grandes panegíricos son modelos, entre otras cosas, "por causa de celebrarse en (ellos) cosas ciertas i que ninguno de los oyentes duda» ${ }^{109}$. Las ideas de Codorniu coinciden con las de reformistas que, hay que subrayarlo, son posteriores a él y que participaron de la misma concepción: «será nuestro cuidado instruir el pueblo con las doctrinas sacadas de la Escritura Santa, de los Concilios, de los Padres de la Iglesia, de la Historia Eclesiástica y de los hechos mas ciertos y recibidos de las vidas de los Santos» ${ }^{110}$.

Por supuesto, el interés por la crítica histórica, introducido por los novatores a fines del siglo XVII y adoptado por algunos de los grandes reformistas de la época, afectó también a la predicación. La exigencia, por parte de los preceptistas, de que las noticias incluidas en los sermones fuesen rigurosamente auténticas, fue capital; las

107. CODORNIU, Antonio: El predicador evangélico..., p. 68

108. Ibídem.

109. MAYANS, G.: «El orador Christiano»en Obras completas (II), III, 85 .

110. AQUINO, Fr. Nicolás de: El púlpito..., insiste en las mismas cuestiones citando a Muratori; «en los Panegíricos, dice un Sabio moderno, se gasta mucho tiempo en referir y contar milagros y tal vez en exageraciones importunas, y dichos muy agudos; y a la verdad se debían mas bien referir las causas necesarias, que no los efectos de la santidad.» (MURATORI, L. Antonio: Ventajas de la eloqüencia popular. Joachim Ibarra, Madrid, 1780, p. 55).

A este tipo de predicadores se refirió L.A. Muratori en los siguientes términos: «no falta quien tenga por lícito el traer al púlpito milagros, privados enteramente de examen, y de testimonios seguros, tomados de gazetas, o de relaciones subrepticiamente impresas, suponiéndolos acaecidos en países remotos, y sin especificar el nombre de quien ha recibido la gracia» (MURATORI, L. A.: Ventajas de la eloquencia popular, p. 124). 
pruebas, sin embargo, se confundían muy a menudo con los testimonios de las autoridades. Cuando Antonio Sánchez se refería a las vidas de los santos diciendo que los predicadores debían usar, por su rigurosidad, las obras de Nain de Tillemont, el Cardenal Baronio o los Padres Papebroch y Bollando que «(...) recogieron con imponderable trabajo, y singular discernimiento, quanto hay escrito sobre las vidas de los Santos, purgando los hechos verdaderos de las circunstancias fabulosas, y refutando los apócrifos»" $"$.

Lo cierto es que los reformistas exigieron que los contenidos de los sermones debían ser verdaderos para que así éstos pudiesen ser calificados como tales ${ }^{112}$.

Lo que había detrás de todas estas precisiones era no sólo el intento de recuperar el rigor dogmático de los sermones sino, también, de volver a una religiosidad más provechosa para los fieles. De este modo, el eje sobre el que se debía vertebrar el panegírico y la adoración de los santos no era tanto el de la devoción o alabanza de sus actos, como el aprendizaje moral. El Santo era propuesto como modelo para la comunidad cristiana. Esta es una de las ideas que más se destacan en las reflexiones de nuestro autor sobre esta cuestión. Reconoce que aunque el predicador:

«Aplaude de los santos lo que es admirable... exhorta a lo que es imitable. Instruye en su verdadera devoción y poderosa intercesión: insta, anima a su imitación. Hombres fueron como nosotros, mas no vivieron como nosotros. Gozaremos de lo que gozan, si hiziéremos lo que hizieron. Alabar a los Santos, y no procurar la santidad ofende su grandeza y condena nuestra tibieza» ${ }^{113}$.

111. SÁNCHEZ, Pedro Antonio: Discurso sobre la eloquencia sagrada en España. Madrid, 1778, p. 122. ¿A qué tipo de narraciones se referían nuestros autores?. En los panegíricos barrocos se incluían exempla que narraban sucesos maravillosos. Era muy habitual en la época la «..difusión de prodigios y milagros, espantoso(s) las más de las veces». Fray Jaime Barón y Arín en su Luz de fe, y de la ley, entretenimiento Christiano entre Desiderio y electo, maestro y discípulos, publicada por primera vez en 1717 incluye el siguiente diálogo: «ELECTO- ¿Se ofende Dios de que no se veneren como merecen las santas reliquias?

Desiderio- $i$ Quién, siendo Católico, puede dudarlo? Los hugonotes de Francia abrasaron en Flandes una Iglesia de San Huberto, donde se guardaban sus reliquias (...) quedaron todos ciegos.

Una mujer llevaba ceñido el cordón de San Francisco, y queriendo ordeñar a una vaca, ató con el cordón al ternerillo, y luego éste cayó muerto (...) atando a otros terneros (...) luego cayeron muertos» (SÁNCHEZ LORA, José Luis: «Claves mágicas de la religiosidad barroca». En ÁLVAREZ SANTALÓ, León Carlos / AGUDO TORRICO, J. (eds lit.): La religiosidad popular. Tomo II. Barcelona. Ed Anthropos, 1989, p. 135).

112. «Tendremos gran cuidado que los asuntos de nuestras oraciones sean verdaderos, para que así lo puedan ser igualmente las pruebas, y no haya necesidad de torcer el sentido de la Escritura y sus Textos. $¡ \mathrm{O}$, qué abandono y falta de consideración hay en esto!... (en) el deseo de abultar la ponderación, y de predicar algo nuevo sobre lo que predicaron las primeras Lumbreras de la Iglesia» (SALAS, Francisco Gregorio de: Compendio práctico del púlpito. Madrid, 1771, p. 78).

113. CODORNIU, Antonio: El predicador evangélico..., p. 48. Aquí entrevemos uno de los rasgos comunes que tiene la obra de Codorniu con la reforma de la predicación emprendida en España desde las centurias anteriores. Diego Murillo, uno de los reformistas del Seiscientos, afirmaba «que todo el tiempo se les ha de pasar(...) en alabar a los Santos sin tratar de la reformación de las costumbres. La verdad es que en las festividades de los Santos muy señalados(como son los dos Joanes, y los dos Apóstoles, San Pedro y San Pablo, y en la de otros cuando se predica en sus propias iglesias) licencia 
Aquí se distanciaron claramente los reformistas de las prácticas habituales en los sermones barroquistas ${ }^{14}$, que sólo servían para el envanecimiento y que no aportaban ninguna lección moral a los fieles ${ }^{115}$. Por el contrario, Codorniu advirtió que «ningún sermón Panegírico lo sea tan del todo, que no tenga por lo menos alguna parte Moral: la más a propósito es la última, porque assí más fácilmente se lleva la instrucción el oyente» ${ }^{116}$. E, incluso, llegó a reducir las razones del culto de los santos a unos motivos éticos: «¿Porque los Santos fueron Santos, y como a tales les obsequia la Santa Iglesia? No por otra razón, sino porque, según las leyes, y consejos Evangélicos, despreciaron las riquezas, pisaron el mundo, huyeron de las honras, perdonaron, y gratificaron las injurias, negaron su voluntad propria, se conformaron con la divina, y finalmente murieron en la Cruz, o de la mortificación, o del martyrio» ${ }^{17}$. Y Codorniu pone como ejemplos de esta práctica a algunos de los grandes predicadores cristianos, como San Bernardo, San Ambrosio, San Agustín, etc. ${ }^{118}$

En último lugar, y debido a su extraordinaria importancia en las polémicas teológicas de este siglo, hemos de hacer alusión a la pastoral del miedo que tanta importancia tuvo en la predicación de la Edad Moderna. En efecto, el empleo de la muerte como elemento esencial para conseguir un estado de shock que permitiese la posterior conversión de los fieles tuvo un enorme protagonismo en los sermones. Frecuente-

ay de alargarse más en tratar sus excelencias; pero nunca la ha de haber para dexar totalmente el fruto que se puede sacar de la doctrina del Evangelio. Y también se ha de huir el extremo de otros predicadores, que así se olvidan de tratar las alabanças del Santo; como si la Iglesia no pretendiese en sus fiestas aficionarse a ellos para tomarlos por intercesores y hazernos imitadores suyos» (HERRERO SALGADO, F.: La oratoria sagrada española de los SS.XVI-XVII, p. 324).

114. Entre las numerosísimas reflexiones sobre esta cuestión citaremos solamente las de Gregorio de Salas, uno de los reformistas de la predicación de la segunda mitad del XVIII que retoma esta idea de Codorniu: «huiremos las indiscretas laudatorias que se han introducido en las Salutaciones, especialmente predicando a Cofradías y Comunidades; cuyo vicio se estiende con demasía en los sermones de Honras, Profesiones de Monjas y Panegíricos: en ellos y en todos los demás debemos abandonar el uso de la Mythología, y en vez de ella y sus fabulas fantásticas y abultadas, llenaremos nuestros discursos de Escritura y sentencias de los Padres» (SALAS, Francisco Gregorio de: Compendio practico del púlpito, p. 29).

115. Es más, parece ser que algunos argumentaron que: «...moralidad en Panegíricos es o mismo que un triste luto en la fiesta» (CODORNIU, Antonio: El predicador evangélico..., p. 64). Opiniones que coinciden con las sostenidas por muchos tratadistas o predicadores del siglo XVII: «Pero dexemos esto (los asuntos morales), porque no es proprio del día: no melancolicemos la fiesta» (HERRERO SALGADO, F.: La oratoria sagrada española de los SS.XVI-XVII, p. 324). Hay muchos ejemplos de esta situación, puede consultarse: ISLA, José Fco de: Crisis de los predicadores y de los sermones Editado por MARTÍNEZ DE LA ESCALERA, J. (S.J.). Ed. Universidad Pontificia de Conillas. Madrid, 1994. Este manuscrito es obra temprana de Isla, está fechado en 1724, pp. 94 y ss. Por supuesto, hay buenas pruebas de este tipo de sermones en ibídem: ISLA, José Fco. de: Historia del famoso predicador fray Gerundio de Campazas (...), p. 254. Teófanes Egido ha recogido opiniones similares del franciscano Sebastián Sánchez Sobrino (EGIDO, Teófanes: «Religión», p. 767).

116. CODORNIU, Antonio: El predicador evangélico..., p. 64.

117. Ibid., p. 66.

118. Ibid., pp. 65 y s. 
mente se usaron elementos plásticos que la recordaban; en otras ocasiones se realizaban descripciones realistas ${ }^{19}$, caracterizadas por el enorme detallismo y la observación fisiológica de los cadáveres, esqueletos, etc. La orden ignaciana fue protagonista de este tipo de prédica desde su fundación ${ }^{120}$.

La referencia a los castigos del infierno, es decir, a los males que siguen a la muerte fue mucho más importante que ésta, «el temor natural a la muerte no debía ser abandonado a sí mismo. Se trataba de dar a este sentimiento una dirección determinada, de prescribirle su objeto, a fin de que el creyente sepa qué es lo que debe temer y aprenda a pintarse los horrores de la muerte como conviene a un cristiano» ${ }^{121}$. Había, pues, otro componente esencial de la pastoral del terror que tenía, si cabe, mayor importancia que la muerte y que nos permite relacionaria con la culpabilización: el análisis de conciencia y el arrepentimiento y, por extensión, con la atrición y la contrición. El fallecimiento era el preámbulo de un momento mucho más importante: «El creyente no temerá a la muerte como tal, sino al infierno, al juicio final» ${ }^{122}$. De este modo, el recuerdo de las penas del infierno y de los castigos eternos tuvieron como fin posibilitar el arrepentimiento de los fieles, la atrición; es decir, la conversión no por amor a Dios sino por el miedo a castigo.

Como es sabido, los rigoristas, estaban influidos por las ideas jansenistas respecto a esta cuestión ${ }^{123}$. La prédica atricionista se dio especialmente en las misiones; el objetivo principal de estos sermones era:

«(...) escitar la atrición, y así apelan únicamente a la pintura de los tormentos eternos, y a cuanto puede aterrorizar a los oyentes» ${ }^{124}$.

119. Codorniu alude a la necesidad de reflexionar sobre la muerte para evitar sus males, especialmente la condenación a la que aludiremos posteriormente. Criticando los sermones dirigidos simplemente al lucimiento del predicador dice que «... sólo cubre(n) y encubre(n) la muerte a nuestros ojos. Ant. Mas dizen que lo contrario disgusta, y atemoriza a los oyentes. Pab. Disgusten en hora buena y oygan la verdad y queden sanos. ¿Pues qué? ¿No espantará más la muerte en su realidad que en la viva y clara representación si ahora no se medita su memoria?» (CODORNIU, Antonio: El predicador evangélico..., pp. 23 y s.).

120. DELUMEAU, J.: Le péché et la peur. La culpabilisation en Occident. XIII(e)-XVIII(e) siécles. Ed. Fayard. Paris, 1983, p. 397 y ss. A este respecto son muy interesantes algunos estudios como el de Bernard Dompnier, quien dice que en los sermones de esta orden se adaptaban los contenidos propuestos en la primera semana de los Ejercicios, es decir, la:«méditation sur l'enfer, larmes pour les péchés, tous les principes fondamentaux de la pastorales missionaire sont autant d'adaptations, à l'échelle du groupe, des méthodes développées dans la première partie des Exercices, pour l'individu auquel on les "donne"» (DONPIER, Bernard: «La Compagnie de Jésus et la mission de l'intérieur» en GIARD, L. y VAUCELLES, Louis de (eds.): Les jésuites à l'âge baroque: 1540-1640. Ed. Jerôme Millou, Grenoble, 1996, p. 178). Los Ejercicios se acercaron, pues, a las masas, a los hombres corrientes.

121. CARO BAROJA, J.: Las formas complejas de la vida religiosa, p. 91.

122. Ibid., p. 92.

123. Estas fueron popularizadas por la obra de Arnaud: La comunión frecuente.

124. ENCISO CASTRILLÓN, Félix: Lecciones y modelos de elocuencia sagrada y forense. Imprenta de la viuda de Calleja e hijos. Madrid, 1840, pp. 59 y s. 
El modelo de oración moral propuesto por Codorniu se asemeja a este tipo de sermones, ya que el predicador debe «...amenazar con el castigo y animar con el premio» ${ }^{125}$.

Este tipo de materiales, las alusiones a los castigos del infierno, a la condenación, etc. estaban destinados fundamentalmente al pueblo llano. En opinión del Padre Codorniu y de otros muchos tratadistas de la época, el pueblo era incapaz de alcanzar unas formas más elevadas de vivencia de la religión.

«(Los) Assumptos mixtos que contengan doctrina para rudos y discretos. $Y$ dado caso, que la materia que se predica sea más proporcionada a los rudos, se elevará una u otra vez con alguna más alta y delicada consideración, v. gr. si predicas del Infierno, pondera qué cosa es perder a Dios por toda una eternidad. Porque esto haze más fueza al oyente sabio que no el fuego y las cadenas, la pena de sentido y horrosa vista de los demonios. Todo lo qual aunque a todos debe mover y atemorizar haze, no obstante, más impressión en los rudos que el perder a Dios» ${ }^{126}$.

De cualquier modo, en la obra de Codorniu no se observa ninguna novedad respecto a la prédica del miedo ${ }^{127}$. En realidad, la presencia del amor y del miedo en la predicación popular estaba presente desde hacía mucho tiempo ${ }^{128}$ :

«Essa especie parece que es de condición muy austera, y aun quería dezir áspera, y terrible. Pab. No es tal, sino grave, y seria; y que muchas vezes templa su rigor con la suavidad, y dulzura; con la qual ruega, solicita, y suplica, por el aprecio de la divina gracia, limpieza de la conciencia, deseo de la virtud, y amor de Dios; y por abreviar, no obra tanto como Juez, como reprehende, y condena, quanto como Padre, que se enoja, y castiga, porque amas ${ }^{120}$.

El predicador no debía silenciar «...(les) rigueurs de la justice divine, de la misère de la vie, de la malice du péché, ou de l'éternité des tourments de l'âme... Malheur au prédicateur complaisant... qui cherche rassurer son public» ${ }^{130}$.

125. CODORNIU, Antonio: El predicador evangélico..., p. 22.

126. Ibid., pp. 11 y s.

127. RICO CALLADO, Francisco Luis: La reforma de la predicación..., pp. 220-234

128. «no negaremos que(...) el terror consigue atraerlos al camino que debieran andar guiados por el amor, y la debida gratitud a lo continuos beneficios que de Dios recibimos, al cabo una vez que sigan el camino que acerca a las virtudes y separa de los vicios, siempre es irse acercando a cumplir la ley divina, y alcanzar los eternos premios ofrecidos a sus fieles observadores» (ENCISO Y CASTRILLÓN, F.: Lecciones... p. 60). «(...) las acciones propias y obligatorias de cada estado: persuada a su cumplimiento con exemplos, con razones, con amenazas, con promesas». (AQUINO, Fr. Nicolás de: El púlpito..., p. 44).

129. CODORNIU, Antonio: El predicador evangélico..., p. 23.

130. SAUGNIEUX, J.: Les jansénistes espagnols et le renouveau de la prédication, p. 94. 